\title{
The Russian Concept of Social Informatics in Light of Information Technology Innovation: A Systematic Review
}

\author{
Nina I. Melnikova (D), Olga A. Romanovskaya \\ Faculty of Sociology, Saratov State University named after N.G. Chernyshevsky, 83 Astrakhanskaya Street, Saratov, 410012, Russia
}

Corresponding author: Nina I. Melnikova [Нина Ивановна Мельникова] (melnikovani@sgu.ru)

\begin{abstract}
The article presents a focused analysis of the Russian-language scientific literature of the first decades of the twenty-first century on the problems of the development of social informatics in Russia. The authors have shown that the multidimensionality of social informatics causes an increasing interdisciplinary research interest in the professional community and is divided into four directions. First, researchers refined the conceptual foundations of social informatics. The second direction is devoted to the study of information resources in their dynamics. The third direction considers and analyses digital traces and their use under the conditions of digital transformation. The fourth direction is devoted to the problems of children and young people in the information environment. The authors achieve intermediate results. Firstly, the clarification of the conceptual basis of the study of social informatics is due to the public demand for comprehensive informatization. Secondly, interest in information resources is due to the need for effective organization of data series in information systems. Thirdly, the accounting and analysis of digital traces and their use are due to the public need for collective security. Fourthly, it is necessary to observe the problems of perception and use of digital technologies by children and young people, as well as their socialization in the developing information society. Finally, the authors conclude that the potential of social informatics is increased by an interdisciplinary interest in qualitative changes in Russian society in the context of digital transformation.
\end{abstract}

\section{Keywords}

Social informatics; Digital transformation; Social media; Information resources; Information society; Digital footprint; Childhood in information society; Information safety.

\footnotetext{
Citation: Melnikova, N. I., \& Romanovskaya, O. A. (2021). The Russian Concept of Social Informatics in Light of Information Technology Innovation: A Systematic Review. Acta Informatica Pragensia, 10(3), 301-332. https://doi.org/10.18267/j.aip.172 


\section{Introduction}

The term "social informatics" has been introduced repeatedly in the context of rethinking the content of this field of study (Smutny and Vehovar, 2020). The multifaceted nature of the term "social informatics" allows us to consider it an umbrella term that unites the views and ideas of researchers who seek to understand the role of digital technologies in society, predict the evolution of society and find ways to reduce the negative impact of digital technologies. Technologies intuitively understood as synonyms have different names in different historical eras: computer technology, information technology and digital technology.

The process of adapting these technologies was also called differently in different historical eras: computerization, informatization and digitization. The renaming process has continued until this day. Nowadays, the term "digital transformation" has become the defining term for the productive adaptation of digital technologies. With changes in terminology, the subject, status, range of main problems, applications, methods and limits of the application of the solutions are also changing.

The uniqueness of social informatics is that its problems are determined by the development of computer technology and the development of appropriate algorithms and programs. The generational change in computer technology and the expansion of the possibilities of software have updated the problems of social informatics, and generational changes of the web are currently determining the problems of social informatics (Klenov et al., 2017). The idea of the social web has spawned many social networking services and social media, eventually leading to the emergence of social platforms.

The periods of web development are commonly referred to as Web 1.0, Web 2.0 and Web 3.0. Web 1.0, also known as the transactional web, creates a network of documents, or the web of documents. Web 2.0, or the social web, promotes simple and useful social interactions on the Internet. Web 3.0, or the semantic web, completes the transition from the document web to a heterogeneous, unstructured data web.

Social networks are the main part of the social web. Semantic web technologies can be used to analyse data from social networks. The semantic web is not just about displaying data but also integrating them and drawing conclusions from huge datasets based on descriptive logics.

Social networks are important tools for controlling society and the self-organization of individuals. Data extracted from social networks can be represented in terms of ontologies. The ontologies can be viewed as the evolution of relational database schemas. For example, The FOAF ontology is used to describe the relationships among individuals (FOAF Vocabulary Specification, 2014). An approach to automatic generation of data from the VKontakte social network into the FOAF ontology format has been proposed (Vagarina et al., 2016).

The VKontakte social network is the most popular social network in Russia, covering 78\% of Internet users in the country. The most popular social network in the world, Facebook, reaches only $34.9 \%$ of Internet users in Russia. Similarly, the numbers of active authors on social networks, that is, unique authors who have written at least one message, excluding private messages, differ across the networks. In November 2021, the number of active VKontakte users was 15.83\%, while the number of active Facebook users was 1.56\% (Brand Analytics - Social Media Monitoring and Analysis, 2021). Thus, the technologies of the semantic web open up unprecedented possibilities for analysis of interpersonal relations on the social web.

More generally, the term "social media" is used to describe a set of tools that allow individuals to interact with each other and form virtual communities. Social media platforms have become crucial for measuring and analysing the structure of relationships in society in order to assess the diffusion of innovations, including those in the social and political spheres. 
A social platform is a collection of hardware and software tools that enable performance in all stages of the problem-solving life cycle in a specific subject area by utilizing artificial intelligence algorithms. Social platforms are designed to structure and manage the society. As for the conditions for the functioning of social platforms, the main issue is control, not over material factors, but over people's behaviour, over their needs, over goal setting through information pumping-on, extensive video surveillance, various social scoring systems, and turning on social lasers.

"Social laser" is a metaphor. In scientific terminology, this research area is called Stimulated Amplification of Social Actions (SASA). Social laser theory presents a general scheme for generating giant waves of social action. This scheme involves several stages. First, the human environment is pumped up with social energy. Then, coordinated social actions are stimulated by injecting a packet of homogeneous messages into the energized environment. In the social laser, the social media play the role of resonators, following the terminology of the physical laser (Khrennikov, 2020). Accordingly, new concepts have emerged that need to be carefully examined as they form the basis for the conceptual control of society.

Computer networks have reformatted all aspects of human life and are considered a qualitatively new factor in system security (Kravchenko and Podberezkin, 2016). There is even some doubt about the balance of opportunities and threats posed by social networks. As a result, recommendations are being developed to reduce the risks associated with the malicious use of social networking services (Romashkina and Fominykh, 2017). First, this is due to the accumulation of so-called digital traces, which form the digital profile of a citizen and can lead to identity theft.

In Russia, the thematic framework of social informatics as a field of research and study was developed in the early 1990s, which was presented in some scientific articles (Kolin, 1990; Ursul, 1990). The logical consequence of the emergence and evolution of social informatics is the development of a university curriculum for social informatics (Kolin, 2001). This social informatics curriculum was supported by appropriate teaching and learning materials (Kolin, 2000 and 2003).

Social informatics courses are now firmly rooted and sustainable in Russian universities. The content of these courses follows the previously formed concept of social informatics and includes the study of information resources, information potential, information society, the study of patterns of the information process, and human problems in the information society (Kolin, 2011).

As mentioned above, the subject matter of Russian social informatics is information resources, information potential, information society and man in information society. Along these lines, a review was conducted to systematically map the basic concepts of social informatics in the context of digital transformation. Due to the multifaceted nature of the topics considered in the Russian concept of social informatics and the difficulty of pursuing it in its entirety, the review will consider some aspects of information resources, the information society and the situation of people in the information society, which follows the logic described below.

Contemporary information resources have spawned numerous social phenomena, including outings, dating, cyberbullying, noosourcing, social bots, social scoring, digital eugenics, social dementia, and shaming. The emergence of new concepts and terminologies passes through the stage where they are buzzwords, for which there are only English-language terms. National languages simply do not have the time to develop new organic concepts and terms. This feature also applies to publications in Russian.

The social phenomena listed above are mainly based on data generated by online social networks, which are directed by the people themselves. People leave a lot of information about themselves through their searches, comments and likes, which can then be used. In fact, modern man is described as a series of clicks that form so-called digital footprints. 
The basis for developing information resources is the information potential of society. The information potential of society is understood as a set of means, methods and conditions for increased use of information resources. The development of information potential in Russia is implemented within the framework of targeted programmes for developing the information state, which provides for digital transformation in healthcare, elections and education.

Throughout the country, there is the national programme "Digital Economy of the Russian Federation", which provides for the digital transformation of public administration. The study of information potential is therefore largely a review of state and regional programmes in this area, which is an important topic worthy of attention in its own right. The information potential objectively exists in Russia, but its discussion occurs outside the social discourse and remains mainly in the technological and governmental discourse.

In studying the information society, the evolution of this concept is of interest. Originally, the information society was seen as a classless and conflict-free society of consent with a small government and state apparatus. A few decades ago, information technology sparked a euphoria in society with the hope that people would gain unprecedented freedom and opportunities through endless surfing of computer networks.

Now the rhetoric has changed as the freedom of online surfing has been supplemented by the accumulation and use of digital footprints and the creation of what has become called a "digital concentration camp". The structure of society, understood as a stable structure of institutions through which people interact in society, is changing.

There is an institutionalization of society-free structures related to the accumulation, processing and application of networked data. As a result, the concept of the information society needs to be constantly rethought, as its cognition is based on, and not independent of, human experience.

On the face of it, people on social media are completely free to make choices without obvious coercion. Implicitly, however, there is a control over people's behaviour. When their actions are performed according to a hidden algorithm, a person is shrouded in consumer information. A person's identity is alienated, and their behaviour, habits and experiences are collected to serve the interests of others.

The perception of everyday life in the information society covers a wide range, from endless freedom in cyberspace to a digital concentration camp typical of different age groups in society. When we talk about the individual and his social environment in the information society, it is of utmost interest to study how children develop in the new information environment, what new problems children face and how to solve them.

The dangers arising in the information society are absolutely new; therefore, they are overlooked. Older generations can use new information technologies and new ways of consuming information services productively, but their basic attitudes and values are shaped by the culture of books and offline communication. It is characteristic of the older generations that they perceive the information society, if not as a "digital concentration camp", then at least as a society of total control, where Big Brother is constantly monitoring you. For children, the information society, in which Hi-Tech technologies become Hi-Hume ${ }^{1}$ technologies with the loss of privacy and the alienation of personality, is organic to their perceptions.

\footnotetext{
${ }^{1}$ The concept of Hi-Hume technologies (from high-humanitarian technologies) is understood by the authors as technologies for changing and transforming the socio-cultural code. These are technologies that influence thinking, social behaviour, human social mobility, etc.
} 
Therefore, the centre of crystallization in the review is information resources, which objectively act as a generator of new social phenomena. Given their profound influence on social life, examining the lives of children in contemporary information society allows us to better assess the nature and validity of arguments related to the assessment of the development of the information society. Since social software is an integral part of social informatics courses, numerous relevant proprietary software products are also included in the review.

The objectives of this review are to determine the semantic charge of key concepts in social informatics, such as information resources and the information society, in the context of digital transformation, to consider relevant and contentious issues, and to systematize the key features of each of these social informatics topics solely within the Russian-language segment of scientific publications devoted to research questions in social informatics.

\section{Methods}

Structural, semantic and contextual analysis allows us to determine the main directions within the topic of social informatics, namely, the social and technological processes that determine the development of information resources, information capacity and information society. The qualitative information obtained during the review was subjected to narrative analysis and related types of interpretation: intent analysis as an analysis of intentions; objective hermeneutics as an example of the analysis of the latent structures of consciousness; discourse analysis (the sphere of collective ideas about information society, formalized in the form of discourse).

A systematic review was conducted according to the principles of Prisma 2020 (Page et al., 2021). To identify relevant keywords, some keyword selection software tools were used, including: Google Trends (Google Trends, 2021), Keyword Tool (Keyword Tool, 2021) and Yandex Podbor Slov (Yandex Podbor Slov, 2021). The Miratext application (Miratext, 2021) and Dandelion API (Dandelion API, 2021) were used for semantic analysis of texts. Search results were measured using the credibility, accuracy, reasonableness, support (CARS) checklist (Harris, 2020).

The text was semantically analysed using the software tool Miratext, which considers the Russian language's morphology. It created a word cloud and assessed a number of formal text factors, such as wateriness. The presence of keywords has also been checked in the text. The English-language components of the articles, which commonly include title, abstract and keywords, were analysed using the software application Dandelion API. This method allows us to determine the suitability for use in the review of discovered sources using the CARS principle.

To be included in the review, bibliographic sources should focus on specific aspects of the development of social informatics, including information resources, information capacity, information society and the individual in an information society (Kolin, 2011). Peer-reviewed journal articles, social informatics curricula, research and development papers and software were included in the study. Articles written in Russian and published between 2000 and 2021 were considered.

Quantitative, qualitative and academic research on social informatics in universities was also included to examine the popularity of various aspects of social informatics. Articles were excluded if they did not fit within the conceptual framework of the study, which focused solely on technical aspects of information technology. Licensed software was also considered to assess society's readiness to implement certain digital transformation ideas.

The following bibliographic databases and registers were searched to identify papers relevant to the systematic review:

- eLIBRARY.RU (Electronic Library of Scientific Publications in Russia, 2021), 
- CyberLeninka (Scientific Electronic Library CyberLeninka, 2021),

- VINITI RAS Database (VINITI RAS DB Online, 2021),

- INION RAN (INION RAN's Bibliographic Databases, 2021),

- FIPS Open Registers Software (Federal Institute of Industrial Property (FIPS), 2021),

- JESDA (Joint Economic and Social Data Archive (JESDA), 2021),

- EGISU NIOKTR (Yedinaya Gosudarstvennaya Informatsionnaya Sistema Ucheta NauchnoIssledovatel'skikh, Opytno-Konstruktorskikh i Tekhnologicheskikh Rabot Grazhdanskogo Naznacheniya (EGISU NIOKTR), 2021).

Below is a brief description of these databases.

- eLIBRARY.RU is the largest electronic library of scientific publications in Russia, which has rich possibilities for searching and analysing scientific information. The library is integrated with the Russian Science Citation Index (RSCI), a free public tool for measuring the publication activity of scientists and organizations created at the request of the Ministry of Education and Science of the Russian Federation.

- CyberLeninka is a scientific digital library built on the Open Science paradigm, whose main tasks are the popularization of science and scientific activity, public quality control of scientific publications, development of interdisciplinary research, the modern institute of scientific review, increasing the citation rate of Russian science and building knowledge infrastructure.

- The VINITI RAS Database is a federal database of national and foreign publications in natural, exact and technical sciences. The VINITI website contains the complete electronic catalogue of scientific and technical literature registered with VINITI since 1994.

- INION RAN maintains bibliographic databases on social sciences and humanities.

- FIPS Open Registers Software is software for computers supported by the Federal Institute of Industrial Property.

- JESDA is a joint economic and social data archive for preserving the results of empirical research in social sciences and bringing them to the scientific community.

- EGISU NIOKTR is the unified state information system for accounting for scientific research, experimental design and technological activities for civil purposes.

The materials of a number of scientific organizations and foundations described below were also used in this review:

- The Institute of Philosophy of the Russian Academy of Sciences (RAS Institute of Philosophy, 2021).

- The Russian Foundation for Basic Research, which provides targeted, diverse assistance to prominent groups of scientists, supports scientific research initiatives in all major areas of fundamental science through a competitive process following a thorough examination. (Russian Foundation for Basic Research (RFBR), 2021).

- The Foundation for Internet Development, which implements research, education, information and awareness-raising projects aimed at the development of the Internet, study of its effect on users, achievement of digital competence, and safe use of the Internet. (Foundation for Internet Development, 2021).

Using the advanced search tools offered by these databases and registers, we searched for relevant publications by title, abstract, keywords, citation list and full text. The search process began with basic social informatics terminology queries. Then special software tools were used to expand the range of keywords. The search results were exported to the Mendeley software application to ensure the management of bibliographic items and correct citations. 


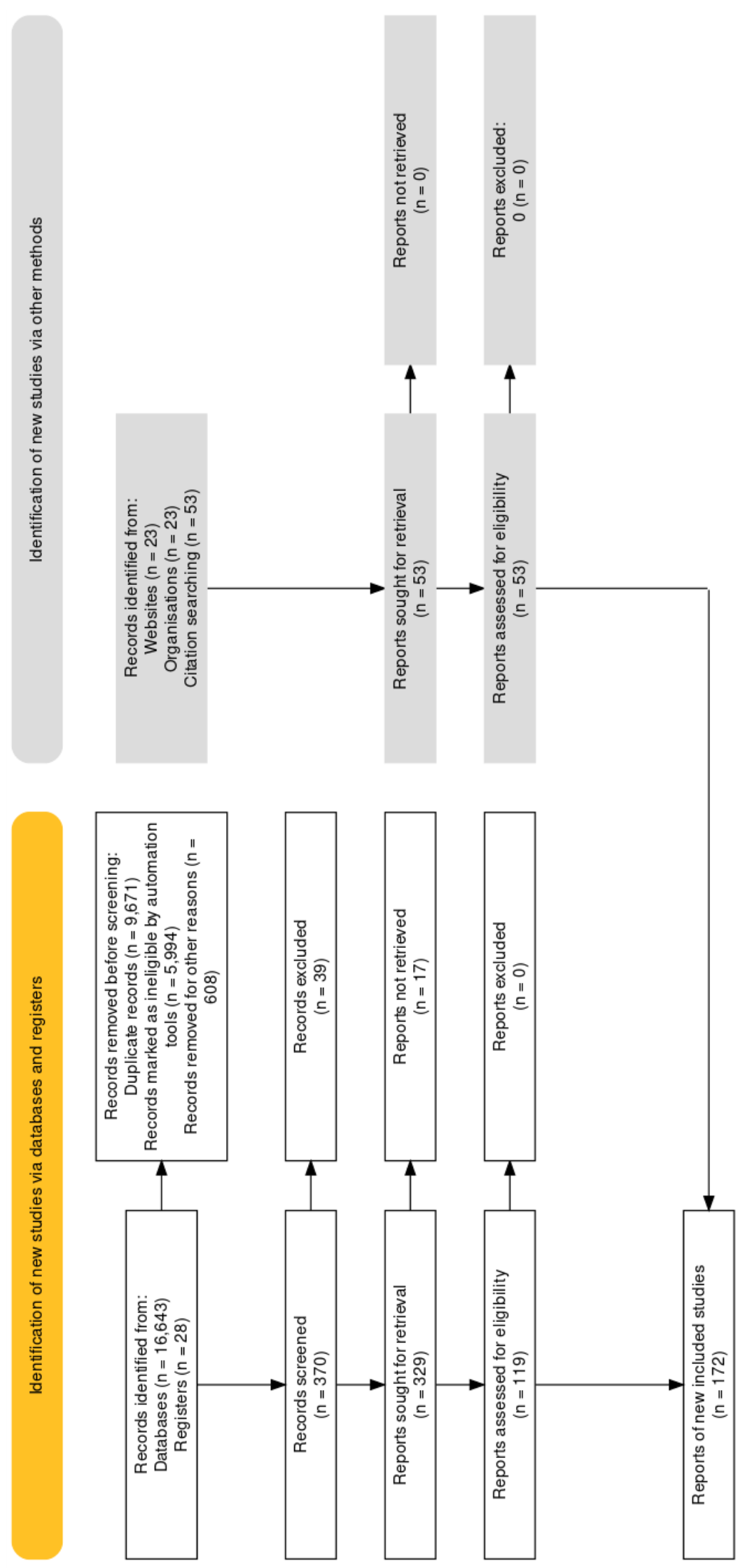

Figure 1. Flow diagram of information items of systematic review. 
Additionally, a search was conducted on the sites of universities that have a social informatics curriculum, including Don State Technical University (Ivushkina, 2018), ITMO University (Chugunov, 2012) Kazan Federal University (Yegorova, 2014), Kazan State University of Architecture and Engineering (Nikonova, 2018), Murmansk Arctic State University (Sagidova, 2016), Novosibirsk State University (Anikin, 2013), Penza State University (Vitetskaya, 2016), Petrozavodsk State University (Moskin, 2020), Platov SouthRussian State Polytechnic University (Zagorodnyuk, 2017), Saratov State University (Sedavkina, 2016), Shadrinsk State Pedagogical University (Yevdokimova, 2016), St Petersburg University (Radikov, 2014), Ulyanovsk State University (Kurilova, 2018), University of Tyumen (Ol'shteyn, 2014), and Volgograd State Medical University (Tokarev, 2016).

To ensure consistency of opinion, all of the bibliographic sources found were reviewed by all the reviewers. The order in which the sources were reviewed was as follows: title, keywords, abstract and full text of the article. In addition, the consistency of the article title, keywords and abstract was ensured. The source was included in the review only if the reviewers reached a consensus.

The selected sources were grouped according to the topics of social informatics, then analysed and summarized on the basis of an expert evaluation of their content. The ideas about social informatics as a field of scientific research and study were expanded and systematized: its subject, status, circle of main problems and applications, methods, capabilities and boundaries.

The PRISMA flow diagram of the systematic review presented in this article is shown in Figure 1. The initial search of the selected databases and registries retrieved a total of 16,633 items of information. By filtering the search results and applying exclusive and inclusive criteria for new searches, 168 items of information were selected and cited in the review.

The process of searching for information items started with macro-queries in databases and registers in the following areas: digital transformation, social informatics, information resources, information capacity, information society, digital footprint, information security. To refine the query, the software tools mentioned above were used to work with the keywords.

\section{Results}

\subsection{Conceptual foundation of social informatics}

The social dynamics of $21^{\text {st }}$ century social development dictate that science should pay close attention to the problems of general digitization. Russian science is sensitive to the national specifics of social informatics. Therefore, methodologically weighty texts by Russian authors demonstrate a clear polyparadigm of research. The emergence of publications that show the conceptual nature of the properties of rationality indicates the recognition of the information society as a stage in the development of civilization.

For example, Laktionov's monograph "The Information Society" (Laktionov, 2004) presents the reader with a scientific study of the stages of formation of the information society theory. The author writes that since the mid-1990s, the Internet has transformed from a specialized military network into a global network. The idea of the information society "acquired flesh and blood", and the information society itself turned from a hypothesis into a reality.

The author analyses the theoretical ideas of Shannon and Wiener and the hypothesis of the emergence of artificial intelligence. He examines declarations of the omnipotence of the Web, explores the process of the emergence of the "network deity", and conducts a practical analysis of the consequences of the informatization of society. 
The collective monograph by Britskov et al. "Social Informatics: Foundations, Methods and Prospects" was the first in the Russian intellectual field to apply a sociocultural approach. The subject and tasks of social informatics were clarified. This collective of authors studied the patterns of secondary analysis of sociological information. They described the methodological rules and organizational forms of accumulating information relevant to Russia. They revealed the phenomenon of "methodological sin" against the traditions of the social sciences. Its essence is the separation of the production of primary data from a meaningful concept of their analysis. They proposed the concept of an open information society (Britkov et al., 2006).

The growing number of publications on information society issues in Russian academic journals demonstrates the intellectual need for serious reflection on the key problems of the information society. Civilization and its laws are becoming increasingly relevant.

The authors of the collective monograph "Social Informatics: Foundations, Methods, Perspectives" edited by Lapin made a significant contribution to solving this problem (Lapin, 2009). The text contains detailed and systematized information that adequately reflects the concept of social informatics as a field of scientific research.

The monograph provides information on the subject, state, main problems, methods and boundaries of social informatics. The authors believe that information society should be recognized as a historically inevitable stage in the development of civilization. This thesis is presented in scientific publications, which reflect the conceptual basis of the properties of rationality and purposefulness. These properties are a necessary characteristic of any technology and technological attitude to the world.

Yudin continues the Russian tradition of conceptualizing the phenomenon of technoscience. He identifies the most obvious feature of technoscience (Yudin, 2006). It is the deeper "embeddedness" of scientific knowledge in the creation and promotion of new technologies.

The book "Internet Addiction: The Psychological Nature and Dynamics of Development" looks in detail at the ways of online behaviour that are specific to internet addicts (adults and children) (Voyskunskiy, 2009). The key question is: what are the signs of Internet addiction and who can be considered an addict? This question is discussed in detail in the pages of the book. There is a view that Internet addiction does not exist as a disease.

The first Russian-language book on Internet addiction presents the full range of opinions expressed and argued by leading Russian and foreign experts on the subject - psychologists and psychiatric psychotherapists. The symptoms thought to be associated with Internet addiction are symptoms of other illnesses. They are independent of the Internet.

A thorough examination of the capabilities of different information management concepts adds to the body of scientific literature (Gilyarevskiy, 2009). The author proposes the concept of management from an informatics perspective: managing organizations that use information, managing information resources and their flows. Gilyarevsky presents knowledge management and information technology in management as an application of scientific informatics. He provides biographies of informatics figures who have contributed to information management.

The monograph "Caught in the Same Net" presents the results of the "My Safe Net" research series. These studies were conducted in 18 Russian regions as part of the Year of Safer Internet in Russia (Soldatova et al., 2011). The total sample consisted of 6,000 schoolchildren, their parents and IT-competent teachers. The study focused on the differences in children's and adults' perceptions of the global web.

Sokolov's book "Information Society in Virtual and Social Reality" presents an analysis of the origin and development of information society ideas in Russia and abroad. The author investigates preconditions and state programmes for building an information society. He describes the technocratic and humanistic 
concepts of the information society. The author reveals the essence of the information society in virtual and social reality, analyses trends in the formation of a global information society and prospects for the idea of its socialization in Russia in the $21^{\text {st }}$ century (Sokolov, 2012).

Intellectual interest in digital socialization not only at the macro level, but also at the micro level has taken hold of Russian scientific discourse through the applied study of social online experiences. Significant results in this respect are provided by the study "Children of Russia Online", conducted by the staff of the Foundation for Internet Development, the Faculty of Psychology of the Lomonosov Moscow State University and the Federal Institute for Education Development of the Russian Ministry of Education and Science. This research is part of the European Commission's international research project EU Kids Online II (Soldatova et al., 2012).

In 2013, the Foundation for Internet Development and the Faculty of Psychology of the Lomonosov Moscow State University, with the support of Google, conducted a nationwide socio-psychological survey "Digital competence of adolescents and parents". The survey was conducted by the Yuri Levada Analytical Centre using a specially developed methodology of the Foundation for Internet Development (FID). A monograph was published based on the results of the survey (Soldatova et al., 2013).

The monograph deals with the scientific approach to the definition and diagnosis of digital competence of individuals in the network society. The results of the first all-Russian study of digital competence of adolescents and parents are presented. The researchers have identified the components of digital competence. These are knowledge, skills, motivation and responsibility in different areas of Internet activities (working with content, communication, technosphere and consumption). The authors showed the need to take into account a person's attitude towards the Internet and the peculiarities of the activity. The authors also discussed the development of educational programmes to build and improve digital competence in adults and adolescents.

The research interest in the social actor in a biographically determined context is presented in "Man in the Information Environment" (Petrova, 2014). The monograph is devoted to the analysis of the socio-cultural aspect of human life in the information environment. This aspect is considered through the prism of the problem of human adaptation of information. The historical roots of the modern information environment and their connection with the dominant way of storing and transmitting information (oral, written, printed, electronic) are analysed. Information culture is presented as a necessary condition for successful human existence in modern society. The author believes that information culture is part of the process of forming the global cultural field of humanity.

In 2015, the monograph "Gaming Worlds: From Homo Ludens to Gamer" was published (Tendryakova, 2015). The author believes that gaming is an invariable companion of human life and human history. The author studied a wide range of games, including ancient games, divination, competitions and modern computer games. The historical and cultural contexts show the transformation of games. The author captures the processes taking place in society and concludes that, as a sociological "seismograph", the game allows us to catch the fluctuations of the social foundations of society.

At the beginning of the $21^{\text {st }}$ century, the game has not only penetrated into all spheres of life but has become a global game and a global civilisational strategy. The author concludes that the game is an integral part of the socio-cultural system. The post-industrial world is a game civilization.

In 2016, a one-volume dictionary "Information Sphere" was published (Gilyarevskiy, 2016). The dictionary is the first unique publication in Russia containing explanations of a wide range of terms related to various aspects of information activities. The Dictionary includes terms related to informatics and information activities, as well as concepts from a number of related fields - computer science, library science, bibliography, bibliology and publishing, which are closely related to each other. 
Contemporary research discourse explains the peculiarities of information and communication technology use in different networked contexts. A team of scholars conducted empirical sociological research and published an analytical review "Russia's Digital Globalization: Competence and Security (2009-2016)" (Soldatova et al., 2017). Vectors of change in digital competence among representatives of the digital generation were identified and studied. The features of Russia's new social situation and digital socialization were described. Problems of online safety were identified and an algorithm for overcoming online risks for adolescents was proposed. The relationship between the characteristics of children's and adolescents' user activity and various parental mediation strategies and children's and adults' digital competence was investigated.

\subsection{Information Resources as Important Topics of Social Informatics}

Following the release of Gromov's well-regarded monograph, the term "information resources" entered the scientific thesaurus (Gromov, 1984). The study of the properties, structure and topology of information resources, as well as the assessment of society's need for information resources and the degree to which they are satisfied, is one of the topics of the Russian social informatics framework (Kolin, 2015).

In the field of information resources, understanding the social and technological processes that shape their production and consumption is essential. At the transactional web stage, information resources were created to update the activities of various companies and organizations, form a new management culture and present the cultural heritage of countries and peoples in modern formats. Under these conditions, the overwhelming majority of users of information resources on the Web were passive readers or users of queuing systems with a predetermined sequence of actions.

The most important technological moment in the transformation of the production and consumption of information resources is the transition from the transactional web to the social web. The transition to the social web and further development of social media led to active participation of users in the creation of information resources and thus had a fundamental impact on them, including the volume of information resources created, topics, timeliness, relevance, age of information creators, etc. As a result of digitization, including destructive social practices, the issues of safe social media use and staying in cyberspace have begun to take on added significance.

Information resources generated by social media are an integral part of the ongoing digital transformation, which has become a universal phenomenon for enterprises, organizations, societies, and human society as a whole. Digital transformation entails the transformation of the public sphere, when the composition of the topics discussed, and the ways of conducting discussion, the ways of presenting and evaluating facts are changed radically. In the context of digital transformation, information resources have become a social engine, shaping social models, laying motivation for behaviour in the subconscious, and becoming a pilot who provides guidance on the rapidly changing trends, identification and formatting of public consciousness.

Information resources have a strong impact on changing the consciousness and worldview of people, since the thought process of a significant part of society proceeds in line with the given network information resources. The consequence of this is the emergence of dataism, which is one of the directions of transhumanism (Kovba and Gribovod, 2019). Dataism is based on the idea that everything consists of data streams and that the value of any phenomenon or entity is determined by its contribution to data processing (Ivanova and Sidorenko, 2020).

When discussing the topology of modern information resources in cyberspace, it should be noted that a significant number of information resources are created by social media, which both reflect and shape society's dominant mentality. However, for monitoring information resources, e.g., for the social and 
humanitarian sphere, information resources are considered to be created in libraries, archives, museums, scientific organizations, science governing bodies, journals, etc. (Antopol'sky, 2017).

A feature of modern information resources is the integration of various communication channels into a single system, called omnichannel, as well as a variety of formats of information provided, which leads to an increased impact on the minds of people, as the user is convinced through repetition (Zhiburt et al., 2021). As a consequence, a peculiarity of the modern era is that it is not necessary to determine supply, but demand is created by information resources through the supply of new goods and types of entertainment.

Most of the goods are very short-lived and of low quality, so a constant stimulation of consumption, in which entertainment-related content is noticeably predominant, is necessary. Additionally, the boundaries between the working and other spheres of an individual's life are currently being blurred (Hines, 2019). In this case, information technology has an invisible, conflict-free impact on society when there is the possibility of a flexible, timely response to social processes taking place in society (Avdeeva and Nazarova, 2017).

The social media information resources represent important features of strategic discourse in society and its main contexts that unite the different strata of society. The developed typology of contexts can be used for a wide range of tasks, including theoretical (analysis of the development of new concepts and terminological bases of interdisciplinary directions, construction of professional/interdisciplinary ontologies) and applied (in education, logistics, and social practices) (Yelkina et al., 2019). An agenda is formed because of the constant influence of information when the worldview of consumers of information resources is formatted by specifying the object of reflection. In fact, social media have become a high-tech platform for selling ideas and worldviews. As a result, the development of digital technologies has led to the formation of new types of "soft power", resulting in increased mobility of the structural components of "soft power" (Rusakova and Gribovod, 2019). However, even though, in the digital age, the forms of mass spectacle have acquired a universal character in terms of form, at the same time, they are fundamentally national in their content. The main directions of the foreign cultural policy of the states of the digital age are linked to various aspects of soft power (Tuzovskii, 2019).

Social media have led to changes in the qualitative composition of information resource authors, the emergence of new author hierarchies, changes in the boundaries of public discourse, and a sharp decline in the age of information resource authors. In traditional media, there is a certain hierarchy of authors working in certain subject areas. Social media make the information world appear peer-to-peer, creating an illusion of equality between speakers. However, social media have their own ways of building hierarchies of authors and network participants, with the help of social buttons, of which the "like" button is the most famous. Social buttons, which collect and track the behavioural information of social network participants, have become the main source of information for influencing cyberspace visitors and building hierarchies of authors. It should also be noted that provocation in the creation of information resources and the unprecedented lowering of the age of the authors of information resources is possible. First, we should mention the existence of interactive dolls with artificial intelligence. The dolls employ speech recognition technology, allowing them to converse with posts. Young children playing with the doll become the authors of information resources sent to the cloud storage, and thus there is a potential risk of violation of family privacy (Zilberman, 2017).

Social media have led to digitization, including destructive social practices. Scientific understanding of destructive social practices and social destructiveness is represented by the creative legacy of thinkers of the Frankfurt School (T. Adorno, M. Horchmeier, H. Marcuse and E. Fromm). Destructive social practices are actions and intentions aimed at destroying social norms and values, so the issues of safe use of social media and staying in cyberspace are of particular importance. 
Communication practices on the Internet are classified as either constructive or destructive (Gnedash and Ryabchenko, 2014). Constructive communicative practices improve the quality of communication and the life of the individual and contribute to the resolution of problems that arise. Destructive communicative practices violate accepted norms of behaviour, worsen the quality of human life and its interaction with other people, and eventually lead to real damage and safety for the individual, their personal society, and society as a whole. Children and youth environments have received special attention. Researchers have examined the emergence of new social practices and forms of activity within the digital information space that is characterized by destructive content and pose a threat to the safety of young people (Larionova et al., 2021), certain aspects of the commission of crimes related to bringing juveniles to suicide (Tkacheva, 2020), etc.

The development of information resources is directly related to various aspects of social security. The mass use of gadgets makes it possible to spy on their owners literally around the clock. Data collection by any gadget is practically unlimited, and it is impossible to protect oneself from surveillance. Large amounts of data with various uses, thematic focuses and structures have begun to accumulate, and based on these data, social media monitoring and analysis tools have been developed, which refer to cybermetric methods.

If we talk about the volume of information resources on social media, for example, in October 2020, the number of active authors on social media in Russia was 64 million, who wrote more than 1.2 billion public messages. At the same time, there is a quantitative decrease in the age of the authors of these information resources. The share of authors younger than 18 years old in 2020 on the social network VKontakte made up $15 \%$ of the total number of authors. It is also necessary to note some gender specifics in the use of social networks. Instagram has become even more feminine (77\% of women in 2020 vs. $75 \%$ in 2019). YouTube, on the other hand, has become more masculine ( $58 \%$ of men now vs. $52 \%$ a year ago). Tiktok (55\% of women) joined the relatively "identical" VKontakte (55\% of women). Facebook ( $60 \%$ of women), like its sister Instagram, also "favours". Twitter is a social network with a "male" face (60\% men) (Chernyy, 2020).

Threats to women's social security are phenomena and processes through which emergence and development, important social rights and interests are violated. The emerging gender digital divide is seen as a risk factor for women's social security and society as a whole (Kislyakov and Shmeleva, 2018).

Social media have spawned, one might say, new entities, so-called bots. Bots generate large amounts of network data on a topic of concern to society, for example, coronavirus, for propaganda purposes, promoting opposition political content on social networks criticizing the authorities and the domestic health system; conspiracy narratives associated with the danger of mass poisoning of food, water and drugs, as well as the danger of "digital slavery" of the population through massive introduction of biometric data (Vasilkova and Legostaeva, 2020).

With the development of network computing technologies, a direction has emerged that can be seen as a reincarnation of sociometric methods, only not of real social contact groups, but of virtual contact groups generated by social network services (Vagarina et al., 2017). The task of monitoring social networks arises, which fundamentally affects the way people interact in the real world when social media metrics begin to be viewed as social capital (Melnikova, 2012). The basic intention of communication in social networks is the formation of a cognitive variant of social capital (Stepanov, 2014), which is a passive reflection of organizational culture (Demchuk, 2017).

Social media metrics are becoming a type of social capital that is increasingly in demand and, accordingly, requires the development of national social media metrics (Melnikova, 2012). Scientific social network services have revealed an autonomous mechanism of accumulation and publication of their scientific social capital, demonstrated the differentiation of scientists and circulating information flows in the 
scientific world, and offered new ways of integrating scientists for joint creative activities (Melnikova, 2013).

Currently, cybermetric methods are used to analyse the publication activity of researchers and enable the transition from formal quantitative indicators to obtaining expert testimony based on bibliometric indicators (Dadalko and Dadalko, 2019). Based on cybermetric and sociological methods, global and Russian indicators of the degree of citizens' "immersion" in the digital environment are studied, current trends in media consumption are analysed, and the audience is stratified by some characteristics, including time and purpose of being online, gender and age characteristics of users (Pyrma, 2021).

The problem of methods for collecting empirical information in the field of disability sociology and the justification of cybermetrics as a useful method of obtaining unprovoked information on the scale of big data take a special place (Dombrovskaya, 2015). Cybermetric methods are used to analyse problems of youth and determine the main directions, the limits of applicability of these methods (Pal'yanova, 2017), analysis of the influence of network communication on the formation of mental orientations of Russian youth (Parshikov et al., 2014).

To analyse the consolidation of society, methods of cybermetrics using hybrid simulation modelling technologies were used. This allows us to take into account the specifics of the considered subject area, the heterogeneity of the actors of the object of study, and their characteristics and goals to improve the quality of the decisions made (Voronin and Kuznetsov, 2021).

Cybermetric methods, along with elements of traditional content analysis and descriptive analysis, are used to study how different generations perceive historical events through films (Belov, 2020). In addition, cybermetric and discourse methods are used to analyse protest messages in the Russian-language segment of social media. Cybermetric methods made it possible to identify the share of information streams of two types: anti-oligarchic and anti-corruption, their dynamic characteristics, dominant leaders of public opinion, and purposefully creating an information background of protest attitudes in social media (Karzubov, 2017). One of the main threats of social media to the socio-political stability of society is the rapid development of influence on changes in the collective psychology, motivation and behaviour of citizens (Surguladze, 2020).

Cybermetric methods make it possible to trace the emergence of media and communicative trends related to the ambiguity of the informational assessment of the coronavirus pandemic situation and the selfisolation of the Internet audience, as well as the emergence of new digital forms of interaction between individuals in their everyday practices on a real-time scale. The new conditions of daily life have led to an understanding of the new viral disease as a sociopolitical phenomenon that creates conditions for new forms of social consolidation brought about by various responses to the crisis. One of the challenges for the social sciences is the formation of scenarios and explanatory schemes for this phenomenon (Yarmak et al., 2020). The combined use of cybermetric analysis and mass survey methods examines Russians' perception of the credit problem, their assessment of the causes and "culprits" against the backdrop of the "Corona crisis" and the decline in citizens' real incomes (Novilov and Kozlov, 2020).

Another trend in the modern world is the collection of behavioural information in a continuous mode, coupled with artificial intelligence to process it and generate control actions, without time delay. We can remember that the Pokemon Go experiment was launched a few years ago. Catching Pokémon teaches you how to control people's behaviour in real time.

The game allowed entry into houses and business premises with localization and captured a picture of the object's movement. The game Pokemon Go was implemented using augmented reality technology. The meaning of the game can be formulated as an application of augmented reality in the management of human behaviour. 
The game Pokemon Go is also considered a serious threat to the military security of the Russian Federation, as it allows users to receive operational information about the location of secret objects. In this regard, there are proposals to combat this game, which allows us to hide treacherous objects, identify people who violate secrecy, and use the proposed system to obtain operational information about closed objects and territories of the potential enemy (Madatov, 2016).

This game is successfully used by some structures, if not for total surveillance of all players or theft of data from the objects of the regime, then at least for manipulation of fans of this game, because under its "camouflage" can be offered a variety of products and ideas: from the imposition of insurance services to the inclusion of "Pokemon catchers" in the crypto sphere (Dvoryankin, 2021).

The virtual and augmented reality technologies used in Pokemon Go find their application in marketing strategies to promote new products (Bukin, 2020). In this regard, it is of interest to assess the degree of impact of information technologies on real and conditional generations because of the development of information and communication technologies (Akhmetshina et al., 2018).

Social media contribute to the emergence of cybercrime among individuals (Kuchina, 2020). The essence of this phenomenon is the method of implementation. Examples of law and practice response abroad, illustrating the approach of Russian legislators and law enforcement to cyberstalking by court decisions, highlighting the problems of criminal law assessment of cyberstalking-related assaults (Filatova, 2020) are of interest.

Studies of the phenomenon of cyberstalking show that it is not uncommon for a victim to be attacked by a stalker. The experience of foreign countries in the legislative regulation of stalking is considered to define the concept and socially dangerous nature of cyberstalking (Barysheva, 2016). A combination of technological and social factors encourages people to participate in inciting violence and stalking others online (Kobets and Krasnova, 2018).

For adults, separate attention is paid to threats associated with avatar-mediated communication in the context of multiplayer virtual game environments, and a classification of threats to the psychological safety of adult Internet users has been developed (Aysina, 2019). Cyberbullying has become a new form of violence against women, which requires the joint efforts of all states to combat (Nikitina, 2016).

The prevalence of different types of cyberaggression and the degree of emotional reactions to them require differentiated approaches to both the prevention of various cyberaggression situations and the construction of specific coping strategies when confronted with them (Soldatova et al., 2020).

Children are also at risk. Reality demonstrates that despite serious measures taken in Russian and international legislation, the level of threats emanating from the Internet remains extremely high because of the transnational nature of cybercrime and requires measures such as criminalizing the storage of illegal online content. Relevant is the creation of a safe Internet space for children, educational activities and advertising aimed at raising awareness of the problem of aggressive content in the Russian segment of the Internet (Runet) among the public authorities, the Internet community and civil society; and educational activities aimed at increasing the culture of Internet use (Kobzeva, 2017).

Cyberbullying, that is, the public disclosure of information about a person's sexual orientation or gender identity without their consent on social media, the disclosure of information about a person that they would like to hide, has also become widespread (Moroz, 2018). Social media influence the ethics of communication. In particular, the habit of publicly presenting any private information, supported by the accessibility of social media and the need to use it for social life, leads to the proliferation of ethically ambivalent practices, for example, in premarital relationships. 
Online speed dating is a format of speed dating using social media, organized for the purpose of introducing people to each other. In addition, the article presents data from a sociological analysis of online speed-dating communities, including social networks. The social portrait of the participants in speed dating and the peculiarities of its conduct were considered. Thus, speed dating is another form of dating relevant to people with insufficient time (Belinskaya, 2015).

Catfishing is another new trend in online dating. Catfishing is a type of deception in which a person creates a completely virtual identity on social networks. Catfishing may have entirely different goals. Some people love the attention of strangers, while others use their virtual identities to scam their online friends, get them to engage in some sort of relationship, or get them to send money.

Because online dating is on a global scale, a comprehensive study of the global online dating market has been made, identifying the main segments of the market (such as matchmaking, online dating and casual dating), identifying regional proportions, determining the market's main players, determining the market's dynamics, trends and forecasts (Khramov, 2017).

The study of modern information resources shows their importance for the development of social processes. The social web has evolved into a hub for the creation of new information resources. There was also a shift in thematic information resources, as well as the bounds of public debates, the manner in which they were presented, their structure and topology.

Social media revealed the genesis of information processes in society. Social media are increasingly being used to forecast information resource requirements. It is vital to do research into information resources in order to develop the best strategy and tactics for the developing processes of digital transformation.

\subsection{Digital footprints and their use}

Online users generate significant amounts of data called "digital footprints." This is information about an individual, i.e., all trackable data about a user's online activities after browsing the Internet. These data can be used for surveillance, cyber espionage, commercial purposes, controlling social behaviour by identifying needs and the characteristics of online surfing.

Digital footprints are created not only when people freely surf the Internet and use various digital products, but also as part of long-term, targeted programmes and as part of large-scale infrastructures such as e-health, e-government, e-science and e-education.

In the Russian Federation, a federal state system called the "Unified System of Identification and Authentication" (ESIA) has been developed. The ESIA is designed to provide authorized access for participants of information interaction in the unified identification and authentication system to the information contained in the state information systems, municipal information systems and other information systems.

Software tools are developed the ESIA for integration and interaction with the ESIA for use in state, municipal, financial, brokerage lending institutions, banks and insurance companies (Khi-Kvadrat, 2020), for integration of applications in development with the ESIA (Bakhtenko, 2020), and to work with the logic and identification of new bank customers through the account of the ESIA on the bank website to automatically determine the creditworthiness of an applicant, whether a natural or legal person, being Russian residents (Impeltekh, 2020).

The concept of "digital profile of a citizen" was adopted by the Russian Federation in March 2019. The most important point in the organization of personal data security is identification, i.e., the definition of the subject of personal data. The concept of "personal data subject" begins to function as a digital complement to a particular physical person and his environment, actually enriching his personality. Therefore, the quality of these digital twins (adequacy, reliability, completeness, relevance) comes to the 
forefront of security (Dokuchaev et al., 2020). The formation of digital identity is a matter of personal, public and national security. The main carrier of information about oneself is the person himself (Petrov, 2020), who must learn how to form a digital identity (Kondakov and Kostyleva, 2019).

The use of a unified identification system in different sectors of the economy, especially in the banking sector, leads to organizational and legal problems, for which solutions are proposed (Kuzbagarov and Kuzbagarova, 2020). Methods of conducting inspections, detecting potential sources of danger based on biometric data and analysing human behavioural characteristics are being improved (Matyukhin, 2020).

Identifying vulnerabilities in the chain of capturing, transmitting, storing and using biometric data will allow the development of a mechanism to minimize the risks of using this technology (Tarankov and Poroshkina, 2020). It is important to identify the problems in the application of the legal regulation of digital footprints in the framework of the national programme "Digital Economy of the Russian Federation" and the digitization of Russia as a whole (Knyshoid, 2020).

The stated areas of application of digital footprints within the framework of long-term targeted programmes are science, education, forensic science and trade.

In science, a significant phenomenon in its organization on a global scale is the migration of scientists. Digital footprints of scientists make it possible to evaluate their interactions, analyse mobility and evaluate quantitative and qualitative indicators of migration. The digitization of scientometrics is a significant advance, contributing not only to the dissemination of scientific knowledge but also to its protection, and digital footprints are important tools in the analysis of quantitative and qualitative scientific indicators (Sudakova, 2020).

The social network ResearchGate is an example of using researchers' digital footprints to analyse their communication strategies (Dadalko and Dadalko, 2019). The history of the social sciences can be seen as a change of stages related to the nature of the dominant data. For the entire past century, sociological data sources have been surveys, interviews and observations.

The next stage has begun, in which new technologies for producing and collecting big data on aspects of human behaviour that were previously unobservable have played a crucial role. Big data do not come from surveys or interviews. Mobile phones, emails, online banking services, credit card transactions, website browsing, barcode reading, social media and so on all play a role in its development.

Human behaviour is analysed using new methods of production, processing and analysis (Guba, 2018). Political science is concerned with the concept of data diplomacy and its impact on world politics (Tsvetkova and Kuznetsov, 2020).

In education, the concept of the digital footprint of learners has been introduced within the framework of the National Technological Initiative (NTI) (Natsional'naya Tekhnologicheskaya Initsiativa [National Technological Initiative]. EduTech., 2021). The NTI also identified new challenges for the education system in the data age and developed a standard for collecting a digital footprint in education (Informatsionno-Kommunikatsionnyye Tekhnologii v Obrazovanii. Tsifrovoy Sled. Obshchiye Polozheniya [Information and Communication Technologies in Education. Digital Footprint. General Principles], 2021).

A digital footprint is understood as an electronic form of data presentation on the results of a person's educational, professional and social activities, which characterizes the level of his professional competence in terms of the trajectory of personal and professional development. A student's digital footprint is a digital imprint of his current cognitive model, recorded at a certain point in time and showing a particular person's place in a social and professional environment. Based on the results of modelling the trajectory of e-learning, the concept of an electronic training course was designed to form 
and assess the professional competencies of students, taking into account their digital footprint (Shamsutdinova, 2020).

It is possible to use specific digital footprints for organizing targeted cognitive influences on selected target groups and individual users of mobile devices. A consequence of the technical change may be a change in the approach to personality assessment, taking into account the accumulated and stored information to a greater extent (Pravikov, 2020). A number of talent management platforms are also being offered (Gud Data, 2020; Krivokora and Kuznetsova, 2020).

Forensic science investigates the theoretical problem of formulating the definition of a new type of trace, an electronic digital trace. The author substantiates the conclusion that it is necessary to adopt an electronic digital footprint as the most correct term characterizing any footprint formed in the computer space, including the Internet. In addition, the article presents the author's definition of this type of trace, which is understandable to a wide range of people.

The trends and prospects of the formation, as well as the further development of a new branch of forensic technology - "forensic research of electronic digital footprints" - are studied (Ivanov, 2020). The classification and significance of electronic digital footprints in the forensic characteristics of crimes in the field of computer information is of great importance.

Digital footprints are viewed as a separate group of footprints that occupy an intermediate position between material and ideal footprints (Zherdev, 2000). The results of the study of the current practice of detecting, fixing, preserving and forensic examination of digital footprints of a crime are analysed.

Topical problems of criminal proceedings are identified, which are faced by representatives of law enforcement agencies investigating crimes associated with information and computer technologies when seizing and fixing computer information (Semikalenova and Ryadovskiy, 2019). Additionally, to differentiate forensic situations in the conceptual apparatus of forensic expertology, it is proposed to introduce the concepts of active and passive digital footprints (Nikishin, 2020).

In trade, information is needed not only about any organization, but also about any person, his hobbies, interests, marital status, work, political views and attitude towards power. Analysed are the positive and negative economic and social effects of collecting and using such information, including as a factor in strengthening the positions of global companies in the IT sector and developing the economy and trade (Petrov, 2020). Cash receipts, which are digital footprints of purchases, are used to highlight product groups based on an analysis of consumer preferences (Dokukin et al., 2019).

Digital footprints are used in different industries. For example, the digital footprinting of diamond processing is considered an aspect of the digital transformation of the economic system of the diamond industrial complex in Russia. Based on global trends and development trends of high-tech production of diamonds grown in the laboratory, the main challenges and threats to the participants of the complex are identified. This article considers the barriers that the representatives of the complex will face when participating in projects to create a digital trace of diamond processing. New threats and challenges have been identified that can limit the implementation of digitization in the administrative and administrative complexes of Russia (Grigor'eva and Sentizova, 2020).

Based on digital footprints, various social scoring systems are being developed, the data sources for which are social networks (Masyutin, 2015). Social scoring is assessed based on artificial intelligence methods. A unique credit scoring system has been developed for retail lending associated with the word "credit." The system adjusts itself to various social and national groups and provides a high level of accuracy in identifying deliberately unscrupulous borrowers of loans in retail (Semenov and Semenova, 2010).

A new approach was developed to classify clients using the credit scoring method based on data from social media profiles (Skiba and Loiko, 2013). This approach explains the interaction of social networks as 
a new source of data in the credit process. The analysis involved statistical methods of data processing and the corresponding mathematical apparatus. The approach is described within the framework of the experiment. Analysis of network data allows a quick and high-quality analysis of the solvency of potential borrowers, thereby reducing the risks of credit institutions, and conducting the most effective marketing policy (Karimov, 2019). Prospects for the introduction of social scoring in public services are considered, as well as a range of regulatory legal acts that can be used when applying scoring systems (Lazarov, 2020).

Scoring models need to be developed on a sample of the most recent clients, periodically checking the quality of the system, and if it deteriorates, updating or creating a new model. For agricultural organizations, this problem is also determined by the fact that credit support is constantly required (Lyutyagin and Zabaikin, 2019).

Proposals have been developed for the development of a reputation scoring system and its more active use in the process of innovative development of social and labour relations (Komarova and Ezhkova, 2020). Social scoring generates a number of risks, including unauthorized collection of personal data, invasion of privacy, discrimination against a particular person or social group and illegal use of personal data.

It is important to note that the risk of using data generated within the framework of social scoring to influence a person's decision making makes it necessary to legally restrict such actions, unless the person himself explicitly expresses a desire for the information received to be used for such purposes (Minbaleev, 2020).

The accumulation of digital footprints has actualized the concept of identity theft. This term appeared more than 50 years ago and denotes a type of fraud using a person's personal data to carry out various operations on his behalf in order to obtain material benefits. An analysis of preventive measures carried out in various states was carried out, and measures were proposed to improve the legal framework.

Data from foreign studies are presented, and a category known as "the right to be forgotten" is discussed, as well as the possibility of its implementation in Russian reality. Solutions to gaps in the aspects of personal data protection have been proposed (Vasilev and Mukhopad, 2020). It also highlights and analyses recent legislative innovations in this area, and discloses amendments to some legislative acts that are important for resolving the issues under consideration (Atagimova et al., 2017).

The digital influence of the state on society and decision-making related to the fate of its citizens is increasingly based on digital data obtained after processing and subsequent analysis, information models of human activity and objects of the real world in the information sphere. However, making decisions based on digital data raises questions about their reliability, the right to collect and use them, and the responsibility for this activity (Zharova, 2020).

Privacy is a key topic in discussions regarding the digital transformation of society. The results of a survey of the Internet audience on the use of personal data by the state and businesses to solve socially important problems show that practically everyone considers the security of personal data in the digital world to be extremely important, which is reflected in their assessment of possible data manipulation (Polyakova and Fursov, 2021).

A variety of research has been carried out to monitor the population's innovative behaviour, according to data provided in the JESDA Archive (Joint Economic and Social Data Archive (JESDA), 2021). The major goal of the monitoring is to look at indicators of people's attitudes toward science, technology and innovation, as well as the distribution of innovative behaviours in households, innovation skills and perceptions of science, technology and innovation. Some parts of this research are relevant to the field of society's information capacity, including the following: 
2012, Monitoring Innovative Behaviour of the Population (Monitoring Innovatsionnogo Povedeniya Naseleniya, 2012).

2012, Dissemination of Innovative Practices. Considering the use, skills on the Internet and the dynamics of the objectives of the use of the Internet, the use of information and communication technologies in the workplace as well as in leisure activities (Rasprostraneniye Innovatsionnykh Praktik, 2012).

2015, Social Demand for Innovation. According to the survey's findings, Russians' demand for new technologies is relatively modest, and not a single technical solution piqued the curiosity of more than half of the respondents. In comparison, similar tests performed in 2008 and 2010 revealed that respondents were much more interested in technical developments (Sotsial'nyy Spros Na Innovatsii, 2015)

2020, Digital Practices of Russians During the Period of Self-isolation. Approximately three-quarters (76\%) of respondents began to use digital tools more regularly for various routine tasks throughout their period of self-isolation. Half of the respondents had installed additional applications and programs (49 percent). One-third of people (34\%) have learned new skills, and another half $(48 \%)$ expected to do so in the near future (Polyakova et al., 2020).

According to research, modern Russians are quite open to innovation (Arkhipova and Kuchmaeva, 2018). However, approximately $16 \%$ of Russians believe that using the Internet is not required (Abdrakhmanova et al., 2020). The evidence supports Rogers' theory of innovation diffusion, which claims that 16 percent of people in any social system will be "laggards" who will never accept the suggested innovation (Rogers, 2003).

\subsection{Information society and childhood}

The Foundation for Internet Development was established in Russia at the turn of the $21^{\text {st }}$ century. Over the twenty years of its operation, the Foundation's team has implemented numerous projects which effectively contribute to the development of the Internet in Russia. This Foundation is a reputable member of the International Information Security Research Consortium. The Consortium is currently conducting research activities on the application of norms, rules and principles of responsible behaviour of states to ensure an open, secure, stable, accessible and peaceful ICT environment.

The FID research activities are guided by the Okinawa Charter on Global Information Society. The Foundation's objectives are to create a safe Internet space for children and adolescents and to develop the ability and readiness of different generations to make full use of all the possibilities of modern digital technology. These practical activities are reflected in serious scientific publications.

Since 2009, the Foundation has been publishing the information and analytical journal Children in the Information Society (thirty-two issues published to date). The Foundation's publishing activities, in terms of methodological and empirical interest in the individual in the information society, focus on problems of Internet user safety. All issues of the magazine focus on the results of serious empirical research.

The first issue focuses on protecting children and adolescents from illegal and aggressive content (Moya Bezopasnaya Set': Internet Glazami Detey i Podrostkov [My Safe Web: The Internet through the Eyes of Children and Teenagers], 2009).

The peculiarities of Russian schoolchildren as Internet users are revealed through the study of the phenomenon of self-realization in computer games (Vo Chto Igrayem? [What Are We Playing?], 2009). The empirical study "Caught in the Same Net" is supported by scientific reflections on the notions of "real and virtual worlds" (God Bezopasnogo Interneta [The Year of Safe Internet], 2010).

The fourth issue of the Foundation magazine features a study entitled "The Dangerous Edge". The foundation's team studies the problems of teenagers' propensity and addiction to computer games and 
the Internet. They make recommendations for correcting teenagers' behaviour (Odarennyye Deti v Onlayne [Gifted Children Online], 2011).

The fifth issue of the Foundation's magazine contains information about the national domain RU-Runet. The study shows a full-fledged digital generation. The research topic of the issue is "Together at the monitor" (Nasha Novaya Shkola [Our New School], 2012). In the sixth issue of the magazine, an empirical study "Children of Cyberspace" is presented. Analysts are interested in the answer to the question: what is the digital divide? (S Kem Oni Obshchayutsya? [Who Are They Communicating With?], 2013).

The main topic of the seventh issue is the problem of disabled children who do not receive primary education in Russia. According to analysts, in the era of the formation of the information society, it is necessary to provide new and equal opportunities for children with disabilities. In Russia, it is necessary to open the large world of education and art for disabled children with the help of information and communication technologies.

The eighth issue of the magazine contains a study of a unique epistolary genre - spoken electronic language. The topics of dangerous curiosity of children and adolescents are studied. Methods of obtaining content that poses a threat to the health of schoolchildren are identified (Chto Oni Pishut i Chitayut [What Do They Write and Read], 2015).

The ninth issue focuses on the important issue of Internet addiction. Analysts are looking for answers to the question: what is it - a new disease or the costs of a new way of life generated by rapid technological development and rapid cultural transformations? The content of youth personal diaries and records was studied (Iz-Za Interneta Ya Ne Yel, Ne Spal [Because of the Internet, I Didn't Eat, I Didn't Sleep], 2011).

The theme of the tenth issue is the relationship between adults and children in the world of information technology. Analysts are convinced that the values of modern children are largely determined by the processes of globalization, the development of mobile communications and the Internet. Therefore, the conflict of values between parents and children in this century is digital in nature and is determined by the digital gap between generations (Kak Im Pomoch'? [How to Help Them?], 2012).

The eleventh issue of the magazine presents statistics showing that more people are sitting in front of monitors than in front of televisions. Analysts are convinced that the influence of the Internet is growing. The stage has come when we can talk about qualitative changes in society. The research is entitled "Aggressors and victims. Bullying in Russia is becoming a serious problem of online communication" (Rozhdennyye Internet-Revolyutsiyey [Born of the Internet Revolution], 2012).

The twelfth issue presents Russian research in the context of international comparison, devoted to the scale and impact of sexting on adolescents, the views of domestic and foreign sexologists and psychologists on the impact of pornography on children and adolescents, as well as various views on how to solve this problem. This issue presents analytics on the topic of books of the digital generation. The study was conducted among Moscow schoolchildren (Ostorozhno: Seksting [Beware: Sexting], 2012).

The thirteenth issue of the magazine contains an empirical study that showed that adults who do not yet have sufficient knowledge about digital culture will have to learn and shape it themselves, along with children who already live in the digital world, but are in dire need of help and support (Aborigeny Ili Grazhdane Tsifrovogo Mira? [Natives or Citizens of the Digital World?], 2013).

The Foundation continues to publish the results of the study of digital competence of Russian teenagers and their parents (2012-2013) in the fourteenth issue. Sociologists and psychologists show the order in which teenagers prioritize when asked about their life values. (Sushchestvuyut Li Tsifrovyye Aborigeny? [Do Digital Natives Exist?], 2014).

The fifteenth issue of the magazine contains research data reflecting the benefits of modernizing American libraries, as well as the results of interesting Russian projects on the internalization of children's libraries. 
A sociological study entitled "The Big Difference" is presented. It shows a selection of readers' preferences and user activity in the Internet (Bibliotechnyy Bum [Library Boom], 2014).

The sixteenth issue of the magazine is dedicated to verbal aggression on the Web. The results of a study on cyber-attacks are presented. The study, called "Dude, I'm with you! How to resist online aggression", showed that every fourth child respondent has acted as an aggressor online or in real life. The authors of the study concluded that online aggression is much more dangerous than offline aggression, and it is almost impossible to protect its victims (Setevaya Agressiya [Online Aggression], 2014).

The seventeenth issue of the magazine is dedicated to the use of digital technologies by preschool children. The authors of the study identified risk factors in online education for children with a high level of digital competence. Experts note that new technologies open up new opportunities for young children, and with them new risks (Malysh i Aypad [The Kid and the iPad], 2014).

The eighteenth issue of the magazine is dedicated to online shoppers. The "Don't buy, but download" study shows that Russian teenagers make purchases online seven times less often than adults, and ten times less often than their American peers. Researchers are trying to find an answer to the question "Why are such active netizens so far behind in the field of consumption?" (Onlayn-Pokupateli [Online Shoppers], 2014).

The nineteenth issue of the magazine contains a study of the level of digital competence of teachers and students. Analysts have shown that adults do not keep up with children. Children learn new technologies faster and more easily than the older generation, know how to do everything at once, and generally develop so quickly that sometimes parents and teachers can only follow the direction of this development (Sayty Dlya Detey: Tekhnologii Ili Iskusstvo? [Websites for Children: Technology or Art?], 2015).

The twentieth issue of the magazine presents a study of the reflection of privacy on the Internet through information chaos and the structure of personal data (Lichnoye Ili Publichnoye [Private or Public], 2015). The twenty-first issue of the magazine is dedicated to the specifics of messages about ourselves: food, landscape and premises, dogs, cats, hamsters, flowers, our loved ones, in a word, the human environment. This issue presents the results of the five-year work of the project "Help lines for children on the Internet" and the results of the study "Online threats through the eyes of children and adults" (Fenomen Selfie [The Phenomenon of Selfies], 2015).

The next issue of the magazine is dedicated to the phenomenon of friendship on the Internet. A sociological survey entitled "More experience - less risks" shows that for a modern teenager, friendship can begin on the Internet, and not be limited to traditional places for communication, such as school, playgrounds or the street next to home (Druz'ya Po Perepiske [Pen Pals], 2015).

The twenty-third issue of the magazine immerses the reader in the topic "The Internet and Love". It presents an empirical study called "Be predictable!". The findings suggest that the online space is rarely a place for romantic dating, but plays a crucial role in how teens flirt, fight and interact with potential or existing "loved ones." Studying the role that digital and social media play in the romantic relationships of modern teenagers provides insight into how deeply gadgets have entered their lives and how quickly technology itself is changing. Parents of a teenager can help them cope with the difficulties of socialization in a complex modern world or, on the contrary, aggravate their internal conflicts, reduce their adaptive capabilities, thereby contributing to the formation of addiction (Internet i Lyubov' [The Internet and Love], 2016).

The twenty-fourth issue of the magazine is dedicated to the topic of communication outside of social networks. It examines a new situation of communication that has given rise to phenomena unknown before the era of technology, such as "unknown friends". The issue contains a reflection on the topic "The right to be forgotten", which is presented by Urvan Parfentov, coordinator of the Internet security zone 
of the regional public organization “Centre for Internet Technologies” (ROCIT) (Sto Druzey Podrostka [A Hundred Teenage Friends], 2018).

Issue twenty-five is dedicated to the topic of parents and technology. Analysts conditionally divide today's adults, whose lives are rapidly breaking into technology, into technophiles who are happy to master the digital world, and technophobes who are afraid of its negative impacts. The issue presents a study of the phenomenon of technophobia and a study of parents' strategy. The authors talk about how parents of modern teenagers perceived the technological revolution of the early $21^{\text {st }}$ century and to what extent they are ready to help their children in the digital world (Tekhnofily i Tekhnofoby [Technophiles and Technophobes], 2016).

The twenty-sixth issue of the magazine is a special issue dedicated to the Unified School Lesson on Internet Safety (Yedinyy Urok Bezopasnosti [Unified Safety Lesson], 2017). The twenty-seventh issue contains an analytical review of game content, which carries many risks, but even more incentives for the development and adaptation of children to future life (Videoigry: Bolezn' Veka Ili Faktor Razvitiya? [Video Games: Disease of the Century or Development Factor], 2017).

The twenty-eighth issue of the magazine is dedicated to the topic of multitasking in the media. Analysts say that modern children easily cope with powerful information flows, using the "Google effect", when everything can be found on their smartphones. In multitasking reality, they train their attention spans and learn how to distribute them. An interesting addition to the research was the story of Emil Aliyev, a player of the Just Alpha team, which is ranked fifth in the Continental League (League of Legends game), about e-sports (Vospitat' Tsezarya [Raise Caesar], 2017).

The twenty-ninth issue of the magazine is dedicated to the topic of screen time. Various data on the use of digital devices, the Internet and mass media by children and adolescents are presented, both in Russia and abroad. Approaches to considering Internet addiction as the most important online risk are shown. The sociological study is called "Caution: Internet Addiction. How to recognize it and overcome it". It is proved that Internet-dependent children are at high risk of suicide. Scientists do not recommend parents to deprive their child of a computer or mobile device on their own, without prior approval from a specialist (psychiatrist, psychotherapist) (Detstvo u Ekranov [Childhood at the Screens], 2018).

The thirtieth issue of the magazine focuses on artificial intelligence and how it can change education in the future. The general opinion was that humanity is only at the beginning of the path of creating this technology, but it is already gradually beginning to come out of laboratories into reality. Study of the question "School terror: can it be foreseen?" opened a discussion space for finding answers to questions: who is prone to attacks on schools and what warnings should be heeded? Why is this happening and increasing in the modern world, and are cultural stereotypes, the Internet and computer games affected? Maybe, on the contrary, digital communications can help identify teenagers who are prone to such actions in time and prevent a tragedy? (Kak Iskusstvennyy Razum Izmenit Shkolu [How Artificial Intelligence Will Change Schools], 2019).

The thirty-first issue of the magazine contains obvious statements that everyday life has changed dramatically, gadgets are all around us, and the time spent by children and teenagers on the Internet day and night is constantly growing. The scientific community does not have a clear answer as to how screen time is related to the mental and physical health of children, what are the nuances and whether it is possible to somehow regulate relations in the increasingly indissoluble union of a gadget and a child. A study called "With gadgets around the clock? One day in the life of an MSU student" is interesting because in scientific research representatives of this generation are sometimes called "digital children". They were born in the era of the Internet and today do not part with gadgets - tools of cognition and communication. It is time to talk about mixed reality, and representatives of Generation $\mathrm{Z}$ live in a world where offline 
and online spaces intersect, overlap and complement each other (Gadzhety i Zdorov'ye: Mify, Fakty, Diskussii [Gadgets and Health: Myths, Facts, Discussion], 2019).

The thirty-second issue of the magazine contains analytics designed to answer the following questions: were Russian schools and families ready for distance education? What was the most unusual academic year in the history of a post-Soviet school - a big setback or a good experience for the future? How do psychologists, physiologists, teachers, parents and children themselves evaluate the results? What questions did they ask directly, and what discussions unfolded around online learning? (Shkola i Koronakrizis: Kak Izmenitsya Obrazovaniye [School and Coronovirus: How Education Will Change], 2020).

Thus, all the thematic issues of the journal of the Foundation for Internet Development focus on theoretical and empirical issues of digital socialization, digital childhood safety, digitization of education, prevention of online risk encounters and methods of increasing digital competence in children and adolescents.

\section{Discussion}

The systematic review focused on select key concepts in social informatics, such as information resources and information society. Social media are the main sources of new information resources. Social media promote the possibility of a non-deterministic, decentralized process of human conversation in which users shape their information and social environment. As a result, social media reflect both the prevailing mentality in society, the qualitative composition of the authors of information resources and their hierarchies, and a shift in the boundaries of public debates.

Social media stimulate the creation of virtual communities. Sociometric methods have resurfaced because of the rise of social media. Now, however, they are applied to virtual contact groups created by online social services rather than real-life social contact groups, as initially.

The information resources of social media make it possible to control human behaviour by identifying needs based on the digital traces of online surfing. Collection and tracking of participants' behavioural data in social media have become an important source of information that influences visitors in cyberspace, builds their relationships, and has the potential for social laser.

The development of large-scale infrastructures such as e-health, e-government and e-science has created exabyte-scale digital footprints. This fact exacerbates the problem of information security and further develops the information society.

The characteristics of the evolution of the information society, as well as the social issues that emerge in the process, become especially clear while analysing the lives and learning of modern children. Children are the most receptive to new information technologies and are the first to face the challenges of the information society. The findings show that current processes of digital transformation dramatically influence social informatics agendas.

Contemporary Russian social informatics is developing in line with a stable concept (Kolin, 2015). This concept dominates research and development (R\&D) organizations and universities enriched with problems arising from the evolution of web technologies (Klenov et al., 2017).

However, it was found that the social informatics curricula in medical universities and social work students partly use a content interpretation of social informatics that is similar to the German concept of social informatics. The German social informatics paradigm Sozialinformatik is narrowly focused on the use of information and communication technologies (ICT) in social work and the social economy (Smutny and Vehovar, 2020). 
The findings reveal that the processes on the social informatics agenda have a conceptual underpinning as well as theoretical and methodological development. It is also worth noting that modern social informatics has a powerful thesaurus that has been enriched in conjunction with the advancement of online technology. This fact enables relevant definition and investigation of the problems of social development and control, which are fulfilled particularly based on social platforms.

As information technology continues to evolve, further research is needed in the field of social informatics. In particular, it is interesting to study different kinds of capital, including human and social capital, in the information society.

Modern concepts of social stratification are based on different types of capital individuals. Everyone has economic capital; human capital and social capital, which gives them a competitive advantage in today's world.

Human capital includes intellect, education, charm, skills, talent and everything necessary to achieve the existing goals in life. People's mutual relationships yield social capital. On the basis of self-assessment of various types of capital, the class structure of society is assessed (Atherton et al., 2011).

Since people's interactions have shifted to social media, it is now possible to evaluate social and cultural capital effectively and objectively. However, social media not only provide a wealth of empirical data for analysing and forecasting human and social capital but also change how these are accumulated. This makes it possible to acquire trustworthy information regarding the social classes and the social structure of information society.

Further research on social informatics topics can also be advanced by considering the so-called "unpublished sources," first of all, R\&D reports, deposited manuscripts and preprints. Study of the features of the information society seems most important, but that should not detract from the meaning of other components of the Russian concept of social informatics.

Of particular interest is the pondering of the transformation of social structure, social institutions and social stratification of society in conjunction with age-sex pyramids in contemporary information society.

This review presents the peculiarities of the shift in children's lives, education and leisure time in an information society. However, research in the field of information society cannot be limited to children. It should be noted that the importance of studying age-sex dynamics in different countries with the peculiarities of the evolution of the information society and the study of various aspects of social classes, including civil, political and social rights, should not be underestimated.

Age-sex pyramids of society are studied in all countries, and relevant datasets are published. These datasets can be used to produce enriched scientific data that can form the basis of data papers, which represent quantitative data and serve as an objective basis for comparing the development of the information society in different countries under conditions of all-encompassing digitization.

\section{Additional Information and Declarations}

Acknowledgements: The article was written as part of the Saratov State University research activities in scientific fields that correspond to the Russian Federation's priority areas of development in science, engineering and technology.

Conflict of Interests: The authors declare no conflict of interest.

Author Contributions: N.M.: Conceptualization, Data curation, Methodology, Software, Supervision, Writing - original draft. O.R: Formal Analysis, Resources, Visualization, Writing - original draft, Writing - review \& editing. 


\section{References}

Abdrakhmanova, G., Vishnevskiy, K., \& Gokhberg, L. et al. (2020). Digital Economy Indicators in the Russian Federation: 2020: Data Book. HSE. https://doi.org/10.17323/978-5-7598-2194-6

Aborigeny ili grazhdane tsifrovogo mira? [Natives or citizens of the digital world?]. (2013). Deti $v$ Informatsionnom Obshchestve [Children in the Information Society], (13). http://detionline.com/assets/files/journal/13/journal13.pdf

Akhmetshina, A. A., Belyaev, V. A., \& Maksimova, O. A. (2018). The Impact of Information Technology on the Continuity and Conflict between Real and Conditional Generations. The Review of Economy, the Law and Sociology, (3), 134-139. https://elibrary.ru/item.asp?id=36282731

Anikin, Y. A. (2013). Teoriya i metody setevogo analiza na primere sotsial'nykh setey. http://fit.nsu.ru/data /docs/mag/program/2011-2013/TiMSAPSS.pdf

Antopol'sky, A. B. (2017). Information resources of social sciences. The experience in monitoring organizing. Bibliosphere, (3), 78-84. https://doi.org/10.20913/1815-3186-2017-3-78-84

Arkhipova, M. Y., \& Kuchmaeva, O. V. (2018). Social Demand of Russians for Innovation (According to a Sample Survey). Economic and Social Changes: Facts, Trends, Forecast, 11(2), 69-83. https://doi.org/10.15838/esc.2018.2.56.5

Atagimova, E., Potemkina, A., \& Tsopanova, I. (2017). "Identity Theft" as an Independent Offence or a Kind of Fraud. Pravovaya Informatika, (3), 14-22. https://doi.org/10.21681/1994-1404-2017-3-14-22

Atherton, S., Neal, K., Kaura, H., \& Jeavans, C. (2011). Calculator, The Great British class. BBC Lab UK. https://www.bbc.co.uk/news/special/2013/newsspec 5093/index.stm

Avdeeva, E. V., \& Nazarova, E. A. (2017). Communicative and Information Resources as a Form of Regulation of Social Processes. Communicology, 5(5), 86-95. https://www.elibrary.ru/item.asp?id=30504015

Aysina, A. M. (2019). Psychological Safety of Adult Internet Users: A Review of Recent Research. Herald of Omsk University. Series: Psychology, (1), 29-38. https://elibrary.ru/item.asp?id=37209149

Bakhtenko, Y. A. (2020). R-START: GOSUSLUGI - YESIA (RU 2020612265). Federal'naya sluzhba po intellektual'noy sobstvennosti. https://new.fips.ru/registers-doc-view/fips servlet?DB=EVM\&DocNumber=2020612265\&TypeFile=html

Barysheva, K. A. (2016). Definition of the Concept and Socially Dangerous Nature of Cyber-Stalkinge. Advokat, 10, 30-36. https://elibrary.ru/item.asp?id=27188423

Belinskaya, D. V. (2015). Speed Dating as Form of the Premarital Relations. Social-Economic Phenomena and Processes, 10(4), 102-105. https://elibrary.ru/item.asp?id=23702776

Belov, S. I. (2020). Perception of the memorial conflict around the film "The death of Stalin" among russian internet users. RUDN Journal of Public Administration, 7(1), 36-46. https://doi.org/10.22363/2312-8313-2020-7-1-36-46

Bibliotechnyy bum [Library boom]. (2014). Deti v Informatsionnom Obshchestve [Children in the Information Society], (15). http://detionline.com/assets/files/journal/15/15number.pdf

Brand Analytics - Social Media Monitoring and Analysis. (2021). Brand Analytics - Social Media Monitoring and Analysis. https://br-analytics.ru/statistics/am/? locale=en RU

Britkov, V. B., Davydov, A. A., \& Zhukova, T. I. (2006). Sotsial'naya informatika: osnovaniya, metody, perspektivy [Social informatics: foundations, methods and prospects]. Yeditorial URSS.

Bukin, I. A. (2020). The Application of Virtual and Augmented Reality in Marketing. Territory of Innovation, (1), 8-12. https://www.elibrary.ru/item.asp?id=42446593

Chernyy, V. (2020). Sotsial'nye seti v Rossii: tsifry i trendy, osen' 2020. Brand Analytics. https://br-analytics.ru/blog/socialmedia-russia-2020/

Chto oni pishut i chitayut [What do they write and read]. (2015). Deti v Informatsionnom Obshchestve [Children in the Information Society], (8). http://detionline.com/assets/files/journal/8/journal-8.pdf

Chugunov, A. V. (2012). Sotsial'naya informatika. NIU ITMO. https://books.ifmo.ru/file/pdf/997.pdf

Dadalko, V. A., \& Dadalko, S. V. (2019). Metric Studies as a Form of Analysis Of Scientific Productivity. Znanie Ponimanie Umenie, (2), 125-136. https://doi.org/10.17805/zpu.2019.2.11

Dandelion API. (2021). Dandelion API. https://dandelion.eu/

Demchuk, D. B. (2017). Measurement of Cognitive Social Capital in Organization: Approaches and Methods. Institute of Psychology Russian Academy of Sciences. Social and Economic Psychology, (2), 165-183. http://soc-econompsychology.ru/engine/documents/document352.pdf

Detstvo u ekranov [Childhood at the screens]. (2018). Deti v Informatsionnom Obshchestve [Children in the Information Society], (29). http://detionline.com/assets/files/journal/29/29Full.pdf

Dokuchaev, V. A., Maklachkova, V. V., \& Statev, V. Y. (2020). Digitalization of the Personal Data Subject. T-COMM, 14(6), 27-32. https://doi.org/10.36724/2072-8735-2020-14-6-27-32

Dokukin, A. A., Zhuravlev, Y. I., Sen'ko, O. V., \& Stefanovskii, D. V. (2019). Mathematical Model for Selecting Groups of Related Products in the Retail by Digital Traces. Ekonomicheskie Strategii, 21(2), 116-125. https://elibrary.ru/item.asp?id=39286944

Dombrovskaya, A. Y. (2015). Cybermetrics of Types of Adaptation Behaviour of Physically Disabled People in the Field of Sociology of Disability. Research Resalt. Medicine and Pharmacy Series, 1(2), 21-29. 
Druz'ya po perepiske [Pen pals]. (2015). Deti v Informatsionnom Obshchestve [Children in the Information Society], (29). http://detionline.com/assets/files/journal/22/22number.all.pdf

Dvoryankin, O. A. (2021). The Game "Pokemon-Go". New Information Technologies on the Internet. National Association of Scientists, 4(36), 11-18. https://doi.org/10.31618/NAS.2413-5291.2021.4.63

Electronic library of scientific publications in Russia. (2021). ELIBRARY.RU. https://elibrary.ru/

Federal Institute of Industrial Property (FIPS). (2021). About FIPS. https://new.fips.ru/en/

Fenomen selfi [The phenomenon of selfies]. (2015). Deti $v$ Informatsionnom Obshchestve [Children in the Information Society], (21). http://detionline.com/assets/files/journal/21/ 21.pdf

Filatova, M. A. (2020). Criminal Liability for Cyberstalking. Ugolovnoe Pravo, (4), 77-82. https://elibrary.ru/item.asp?id=44430885

FOAF Vocabulary Specification. (2014). FOAF Vocabulary Specification. http://xmlns.com/foaf/spec/

Foundation for Internet Development. (2021). Foundation for Internet Development. http://www.fid.su/

Gadzhety i zdorov’ye: mify, fakty, diskussii [Gadgets and Health: Myths, Facts, Discussion]. (2019). Deti v Informatsionnom Obshchestve [Children in the Information Society], (28). http://detionline.com/assets/files/journal/28/28 web.pdf

Gilyarevskiy, R. S. (2009). Informatsionnyy menedzhment. Upravleniye informatsiyey, znaniyem, tekhnologiye [Information management. Management of information, knowledge, technology]. Professiya.

Gilyarevskiy, R. S. (2016). Informatsionnaya sfera [Information Sphere]. Professiya.

Gnedash, A., \& Ryabchenko, N. (2014). Constructive and destructive socio-political practices in today russia online-space: fail, case, mechanics. Chelovek, Soobshchestvo, Kontrol' / Human, Community, Controlling, (2), 40-54. https://www.elibrary.ru/item.asp?id=21712013

Google Trends. (2021). Google Trends. https://trends.google.com/trends/?hl=ru\&geo=US

Grigor'eva, E. E., \& Sentizova, N. R. (2020). Digital Footprint of Diamond Processing as a Way to Confirm its Origin. Finansovaya Ekonomika, (6), 257-259. https://doi.org/10.25997/FIE.2020.77.6.002

Gromov, G. R. (1984). Natsional'nyye informatsionnyye resursy: problemy promyshlennoy ekspluatatsii. Nauka.

Guba, K. (2018). Big Data in Sociology: New Data, New Sociology? Russian Sociological Review, 17(1), $213-234$. https://doi.org/10.17323/1728-192X-2018-1-213-236

Gud Data. (2020). Platforma upravleniya talantami «Rostelent» [Rostalent Talent Management Platform] (RU 2020662699). Federal'naya sluzhba po intellektual'noy sobstvennosti. https://new.fips.ru/registers-docview/fips servlet?DB=EVM\&DocNumber=2020662699\&TypeFile=html

Harris, R. (2020). VirtualSalt. Evaluating Internet Research Sources. http://www.virtualsalt.com/evaluating-internet-researchsources/

Hines, A. (2019). Getting Ready for a PostWork Future. Foresight and STI Governance, 13(1), 19-30. https://doi.org/10.17323/2500-2597.2019.1.19.30

Impeltekh. (2020). MODUL' YESIA-SKORING SISTEMA (RU 2020665132). Federal'naya sluzhba po intellektual'noy sobstvennosti. https://new.fips.ru/registers-doc-view/fips servlet?DB=EVM\&DocNumber=2020665132\&TypeFile=html

INION RAN's Bibliographic Databases. (2021). INION RAN's Bibliographic Databases. http://inion.ru/ru/english/bibliographicdatabases/

Informatsionno-kommunikatsionnyye tekhnologii v obrazovanii. Tsifrovoy sled. Obshchiye polozheniya [Information and communication technologies in education. Digital footprint. General Principles]. (2021). https://standard.2035.university/

Internet i lyubov' [The Internet and Love]. (2015). Deti v Informatsionnom Obshchestve [Children in the Information Society], (23). http://detionline.com/assets/files/journal/23/23 web.pdf

Ivanov, V. Y. (2020). On Theoretical Aspects of Using the Concept of Digital Footprint in Forensics. Yuridicheskie Issledovaniya, (7), 75-80. https://doi.org/10.25136/2409-7136.2020.7.33682

Ivanova, O. E., \& Sidorenko, E. N. (2020). Digital Transformation in the Labor Market: The Context of the Development of an Online Talent Platform. Financial Economy, (4), 260-262. https://elibrary.ru/item.asp?id=42868327

Ivushkina, Y. В. (2018). Sotsial'naya informatikale. https://www.sssu.ru/rpd/2017/39.03.02 Социальная работа/социальная информатика/рпд зфро.pdf

Iz-za interneta ya ne yel, ne spal [Because of the Internet, I didn't eat, I didn't sleep]. (2011). Deti $v$ Informatsionnom Obshchestve [Children in the Information Society], (9). http://detionline.com/assets/files/journal/9/journal9.pdf

Joint Economic and Social Data Archive (JESDA). (2021). JESDA. http://sophist.hse.ru/eng/

Kak im pomoch'? [How to help them?]. (2012). Deti $v$ Informatsionnom Obshchestve [Children in the Information Society], (10). http://detionline.com/assets/files/journal/10/journal10.pdf

Kak iskusstvennyy razum izmenit shkolu [How artificial intelligence will change schools]. (2019). Deti v Informatsionnom Obshchestve [Children in the Information Society], (30). http://detionline.com/assets/files/journal/30/30 web full.pdf

Karimov, A. (2019). Scoring on the Basis of "Alternative" Data. Recent Achievements and Prospects of Innovations and Technologies, 356-361. https://www.elibrary.ru/item.asp?id=41600696 
Karzubov, D. N. (2017). Mobilization of Russian Social Media Users' Protest Attitudes (2011-2017). Social and Humanitarian Knowledge, (8), 244-257. https://www.elibrary.ru/item.asp?id=30022298

Keyword Tool. (2021). Keyword Tool. https://keywordtool.io/ru

Khi-Kvadrat. (2020). XSQUARE - EChA (RU 2018610542). Federal'naya sluzhba po intellektual'noy sobstvennosti. https://new.fips.ru/registers-doc-view/fips servlet?DB=EVM\&DocNumber=2018610542\&TypeFile=html

Khramov, M. Y. (2017). World Online Dating Market: State and Key Trends. Ekonomika i Predprinimatel'stvo, 12(1), $693-702$. https://www.elibrary.ru/item.asp?id=32560116

Khrennikov, A. Yu. (2020). Social laser: application of quantum information and field theories to modeling of social processes. Jenny Stanford Publishing.

Kislyakov, P. A., \& Shmeleva, E. A. (2018). The Digital Gender Gap as a Risk Factor of Social Safety of the Russian Society Woman in Russian Society, (3), 14-25. https://doi.org/10.21064/WinRS.2018.3.2

Klenov, D. V., Sytnik, A. A., Vagarina, N. S., Melnikova, N. I., Shulga, T. E., \& Kalugina, T. A. (2017). Social Informatics and Web Evolution. Juvenis Scientia, (2), 59-64. https://doi.org/10.15643/jscientia.2017.2.016

Knyshoid, M. Z. (2020). Digital Footprint and its Legal Regulation. Informatsionnoe Pravo, (4), 37-40. https://www.elibrary.ru/item.asp?id=44536195

Kobets, P. N., \& Krasnova, K. A. (2018). About the Social Danger of Cyberstalking and the Necessity of its Prevention. Vestnik Eastern Siberia Institute of the Ministry of the Interior of the Russian Federation, (3), 77-83. https://elibrary.ru/item.asp?id=35644857

Kobzeva, S. V. (2017). Juvenile Right Protection from Internet Threats. Informatsionnoe Pravo, (2), 33-39. https://elibrary.ru/item.asp?id=32525280

Kolin, K. K. (1990). O strukture nauchnykh issledovaniy po kompleksnoy probleme $\backslash$ Informatika [About structure of scientific researches on a complex problem of \Information scientist]. In Sb. nauchn. tr., Sotsial'naya informatika [Collection of scientific works, Social informatics], (pp. 19-33). Vysshaya komsomol'skaya shkola pri TsK KPSS.

Kolin, K. K. (2000). Fundamental'nye osnovy informatiki: Sotsial'naya informatika [Fundamental bases of informatics: Social informatics]. Akademicheskiy Proekt.

Kolin, K. K. (2001). Sotsial'naya informatika. Bazovaya modul'naya programma uchebnogo kursa dlya sistemy vysshego obrazovaniya [Social informatics. Basic modular program of a training course for system of the higher education]. Institute of Informatics Problems RAS.

Kolin, K. K. (2003). Sotsial'naya informatika [Social informatics]. Akademicheskiy Proekt.

Kolin, K. K. (2011). Social informatics today and tomorrow. TripleC: Communication, Capitalism \& Critique, 9(2), 460-465. https://doi.org/10.31269/triplec.v9i2.299

Kolin, K. K. (2015). Social Informatics: Russian Scientific School and Future Research Directions. Systems and Means of Informatics, 25(4), 175-193. https://doi.org/10.14357/08696527150413

Komarova, O. M., \& Ezhkova, V. G. (2020). Reputation Scoring in Innovative Development of Social and Labor Relations. Vestnik Altayskoy Akademii Ekonomiki i Prava, 3(10), 290-295. https://doi.org/10.17513/vaael.1377

Kondakov, A. M., \& Kostyleva, A. A. (2019). Digital Identity, Digital Self-Identification, Digital Profile: Problem Statement. RUDN Journal of Informatization in Education, 16(3), 207-218. https://doi.org/10.22363/2312-8631-2019-16-3-207-218

Kovba, D. M., \& Gribovod, E. G. (2019). Theoretical Aspects of the Phenomenon of Transhumanism: Main Directions. Discourse- $P$, (3), 38-52. https://doi.org/10.24411/1817-9568-2019-10303

Kravchenko, S. A., \& Podberezkin, A. I. (2016). Social Nets as a New Factor of System Security in Russia in the $21 \mathrm{st}$ Century. MGIMO Review of International Relations, 51(6), 14-23. https://vestnik.mgimo.ru/jour/article/view/634/619\#

Krivokora, E. I., \& Kuznetsova, T. A. (2020). Talent Management Platform as a Factor in Increasing the Efficiency of Work with the Personnel Reserve. In Innovatsionnye Napravleniya Razvitiya v Obrazovanii, Ekonomike, Tekhnike $i$ Tekhnologiyakh, (pp. 65-67). Stavropol. https://elibrary.ru/item.asp?id=43129378\&pff=1

Kuchina, Y. O. (2020). The Problem of Extrapolation of Elements of the Criminological Characteristics of a Particular Types of Crime Committed in Cyber Space: General Characteristics of Cyberstalkinge. Rassledovanie Prestupleniy: Problemy I Puti Ikh Resheniya, (3), 47-51. https://elibrary.ru/item.asp?id=44357024

Kurilova, O. L. (2018). Informatizatsiya obshchestva. https://www.ulsu.ru/media/files1/20210205/2018 ИСТ РП Информатизация общества Курилова.1.pdf

Kuzbagarov, M. N., \& Kuzbagarova, E. V. (2020). The Unified Biometric System and Unified System of Identification and Authentication as Tools to Ensure the Security of Banking Operations Using the Internet: Legal and Organizational Issues. The Rule-of-Law State: Theory and Practice, 16(4-2), 199-212. https://doi.org/10.33184/pravgos-2020.4.36

Laktionov, A. (2004). Informatsionnoye obshchestvo [Information society]. AST.

Lapin, N. I. (2009). Sotsial'naya informatika: osnovaniya, metody, prospects [Social informatics. Foundations, Methods, Perspectives]. (3rd ed.). URSS.

Larionova, A. V., Gorchakova, O. Y., \& Fakhretdinova, A. P. (2021). The peculiarities of student activity on the internet: experience of destructive communication and safety issues. Sociodynamics, (3), 12-22. https://doi.org/10.25136/2409$\underline{7144.2021 .3 .35227}$ 
Lazarov, A. A. (2020). Legal Regulation of Social Scoring in the Field of Public Service: Russian and Foreign Experience. Informatsionnoe Pravo, (4), 41-44. https://infolaw.su/biblio/173-informatsionnoe-pravo-4-2020.html

Lichnoye ili publichnoye [Private or public]. (2015). Deti $v$ Informatsionnom Obshchestve [Children in the Information Society], (20). http://detionline.com/assets/files/journal/20/4 80 6.pdf

Lyutyagin, D. V., \& Zabaikin, Y. V. (2019). The Estimation of the Probability of Outflow of Client. Economics: Yesterday, Today and Tomorrow, 9(5B), 543-550. https://www.elibrary.ru/item.asp?id=41860509

Madatov, O. (2016). "Pokemon GO" as Threat of Military Security RF. Informatsionnye Voyny, 40(4), 80-83. https://elibrary.ru/item.asp?id=27249685

Malysh i aypad [The Kid and the iPad]. (2014). Deti v Informatsionnom Obshchestve [Children in the Information Society], (17). http://detionline.com/assets/files/journal/17/ 17.pdf

Masyutin, A. A. (2015). Credit Scoring Based on Social Network Data. Business Informatics, (3), 15-23. https://www.elibrary.ru/item.asp?id=24351093

Matyukhin, O. I. (2020). About the Experience of Aviation Security in Russia and Abroad. Academic Thought, (1), 80-82. https://www.elibrary.ru/item.asp?id=42809185

Melnikova, N. I. (2012). Social Media Metrics as the Social Capital. Vestnik Saratov State Technical University, (1), $256-258$. https://cyberleninka.ru/article/n/metriki-sotsialnyh-media-kak-sotsialnyy-kapital

Melnikova, N. I. (2013). Scientific Social Network Services as the Tools for Differentiation and Integration of the Academic Community. Vestnik Saratov State Technical University, (1), 255-260. http://elibrary.ru/item.asp?id=19415750

Minbaleev, A. V. (2020). Problems of Social Efficiency and Human Rights Protection in the Use of Artificial Intelligence in the Framework of Social Scoring. Bulletin of the South Ural State University Series “Law”, 20(2), 96-101. https://doi.org/10.14529/law200216

Miratext. (2021). Miratext. https://miratext.ru/

Monitoring innovatsionnogo povedeniya naseleniya. (2012). Monitoring innovatsionnogo povedeniya naseleniya. http://sophist.hse.ru/db/oprview.shtml?ID $S=1606 \& T=q$

Moroz, O. V. (2018). Ethical Paradoxes of Network Communication: Online Outing Phenomenon. In Peresekaya Granitsy: Mezhkul "turnaya Kommunikatsiya m Global" nom Kontekste, (pp. 206-207). https://www.elibrary.ru/item.asp?id=34885997

Moskin, N. D. (2020). Sotsial'naya informatika. https://petrsu.ru/files/disc/upload user/Work Prog 593908 39.03.02 11062020.doc?t=1616360648

Moya bezopasnaya set': internet glazami detey i podrostkov [My Safe Web: The Internet through the Eyes of Children and Teenagers]. (2009). Deti $v$ Informatsionnom Obshchestve [Children in the Information Society], (1). http://detionline.com/assets/files/journal/1/journal-1.pdf

Nasha novaya shkola [Our new school]. (2012). Deti v Informatsionnom Obshchestve [Children in the Information Society], (8). http://detionline.com/assets/files/journal/5/journal-5.pdf

Natsional'naya tekhnologicheskaya initsiativa [National Technological Initiative]. (2021). EduTech. https://news.nti2035.ru/tag/edunet/

Nikishin, V. D. (2020). Digital and speech traces in terms of information (ideological) security in internet. Forensic Examination, (1), 131-139. https://doi.org/10.25724/VAMVD.MABC

Nikitina, Y. (2016). International Legal Cooperation in Combating Women Cyber Stalking. Journal of Legal and Economic Studies, (1), 52-58. https://elibrary.ru/item.asp?id=25904238

Nikonova, E. I. (2018). Sotsial'nyye problemy informatizatsii. https://www.kgasu.ru/upload/iblock/775/09.03.02 isit 2015161718 o rpd b1.v.dv.02.01.pdf

Novilov, O., \& Kozlov, N. (2020). Growing Household Credit Load Through the Prism of Social Perception, Credit, and Political Attitudes of Russians. Review of Business and Economics Studies, 8(4), 19-32. https://doi.org/10.26794/2308-944X2020-8-4-19-32

Odarennyye deti v onlayne [Gifted children online]. (2011). Deti v Informatsionnom Obshchestve [Children in the Information Society], (4). http://detionline.com/assets/files/journal/4/journal-4.pdf

Odin v onlayne [Alone online]. (2014). Deti v Informatsionnom Obshchestve [Children in the Information Society], (7). http://detionline.com/assets/files/journal/7/journal-7.pdf

Ol'shteyn, A. A. (2014). Sotsial'naya informatika. https://op.utmn.ru/upload/umkdocs/file umkdocs/552/Annot PO Sinf 2612 2016.pdf

Onlayn-pokupateli [Online shoppers]. (2014). Deti v Informatsionnom Obshchestve [Children in the Information Society], (18). http://detionline.com/assets/files/journal/18/number18.pdf

Ostorozhno: seksting [Beware: Sexting]. (2012). Deti $v$ Informatsionnom Obshchestve [Children in the Information Society], (12). http://detionline.com/journal/numbers/32

Page, M. J., McKenzie, J. E., Bossuyt, P. M., Boutron, I., Hoffmann, T. C., Mulrow, C. D., Shamseer, L., Tetzlaff, J. M., Akl, E. A., Brennan, S. E., Chou, R., Glanville, J., Grimshaw, J. M., Hróbjartsson, A., Lalu, M. M., Li, T., Loder, E. W., Mayo-Wilson, E., McDonald, S., ... Moher, D. (2021). The PRISMA 2020 statement: an updated guideline for reporting systematic reviews. Journal of Clinic Epidemiology, 134, 178-189. https://doi.org/0.1136/bmj.n71 
Pal'yanova, N. Y. (2017). Metody i metodiki issledovaniya kibermetrii i vebometrii pri analize molodezhnykh problem. In Issledovaniya i Razrabotki v Perspektivnykh Nauchnykh Oblastyakh, (pp. 32-36). https://elibrary.ru/item.asp?id=30544198\&selid=30544203

Parshikov, N., Domarenko, E. V., Dombrovskaya, A. Y., \& Stepanchenko, O. V. (2014). The Impact of Internet Communications on the Formation of Value Orientations of Russian Youth (The Results of National Sociological Research). Bulletin of Kemerovo State University of Culture and Art, 29(1), 129-140. https://www.elibrary.ru/item.asp?id=22443911

Petrov, A. (2020). Information and Digital Footprint: Commercial and Social Aspects in the Digital Age. Trade Policy, (2), 6286. https://doi.org/10.17323/2499-9415-2020-2-22-62-86

Petrov, A. A. (2020). Russian Matrix of the Digital Profile of the Russian. National Association of Scientists, (1), 39-52. https://doi.org/10.31618/nas.2413-5291.2020.1.52.144

Petrova, Y. V. (2014). Chelovek v informatsionnoy srede : sotsiokul'turnyy aspekt [Man in the Information Environment: Sociocultural Aspect]. IFRAN. https://iphras.ru/uplfile/root/biblio/2014/Petrova.pdf

Polyakova, V. V., \& Fursov, K. S. (2021). Gotovy li pol'zovateli runeta delit'sya personal'nymi dannymi?. https://issek.hse.ru/mirror/pubs/share/450608071.pdf

Polyakova, V. V., Nesterenko, A. V., \& Fursov, K. S. (2020). Tsifrovyye praktiki rossiyan v period samoizolyatsii [Digital practices of Russians in a period of self-isolation]. https://issek.hse.ru/news/438496284.html

Pravikov, D. (2020). Digital Footprints and Digital Shadows as an Aspect of the Assessment of Cognitive Impacts. Informatsionnye Voyny, (4), 17-21. https://www.elibrary.ru/item.asp?id=44386772

Pyrma, R. V. (2021). Diving the Citizens into the Digital Communication Environment. Vlast', 29(1), 69-79. https://doi.org/10.31171/vlast.v29i1.7891

Radikov, I. V. (2014). Sovremennyye strategii razvitiya informatsionnogo obshchestva. https://spbu.ru/sites/default/files/strategiya razvitiya $0 . p d f$

RAS Institute of Philosophy. (2021). RAS Institute of Philosophy. https://eng.iph.ras.ru/

Rasprostraneniye innovatsionnykh praktik. (2012). Rasprostraneniye innovatsionnykh praktik. https://www.hse.ru/monitoring/innpeople/2012rus

Rogers, E. (2003). Diffusion of innovation. Free Press.

Romashkina, N., \& Fominykh, T. (2017). Internet Social Networks: New Oppotuniteis or New Threats? Informatsionnye Voyny, 46(2), 16-27.

Rozhdennyye internet-revolyutsiyey [Born of the Internet Revolution]. (2012). Deti v Informatsionnom Obshchestve [Children in the Information Society], (11). http://detionline.com/assets/files/journal/11/journal11.pdf

Rusakova, O. F., \& Gribovod, E. G. (2019). Information Components of Soft Power: Communicative Aspects. Mezhdunarodnye Processy, 17(1), 62-72. https://doi.org/10.17994/IT.2019.17.1.56.4

Russian Foundation for Basic Research (RFBR). (2021). Russian Foundation for Basic Research. https://www.rfbr.ru/rffi/eng/info eng

S kem oni obshchayutsya? [Who are they communicating with?]. (2013). Deti v Informatsionnom Obshchestve [Children in the Information Society], (6). http://detionline.com/assets/files/journal/6/journal-6.pdf

Sagidova, M. L. (2016). Sotsial'naya informatika. https://www.arcticsu.ru/wp-content/uploads/2017/10/B1.V.OD.11-Sotsialnayainformatika RPD SotsSotsRab.pdf

Sayty dlya detey: tekhnologii ili iskusstvo? [Websites for children: technology or art?]. (2015). Deti v Informatsionnom Obshchestve [Children in the Information Society], (19). http://detionline.com/assets/files/journal/19/19 2.pdf

Scientific electronic library CyberLeninka. (2021). Cyberleninka. https://cyberleninka.ru/about

Sedavkina, Y. A. (2016). Osnovy sotsial'noy informatik. https://www.sgu.ru/sites/default/files/education/programs/2017/03/osnovy socialnoy informatiki.pdf

Semenov, M. Y., \& Semenova, I. I. (2010). Possibilities of Psychological Tools to Identify Honest Loans Borrowers in Retail Trade. Omsk Scientific Bulletin, (5), 134-136. https://www.elibrary.ru/title about new.asp?id=9601\&langid=2

Semikalenova, A. I., \& Ryadovskiy, I. A. (2019). The Use of Special Knowledge in Detecting and Fixing Digital Traces: Analysis of Modern Practice. Actual Problems of Russian Law, (6), 178-165. https://doi.org/10.17803/19941471.2019.103.6.178-185

Setevaya agressiya [Online aggression]. (2014). Deti $v$ Informatsionnom Obshchestve [Children in the Information Society], (16). http://detionline.com/assets/files/journal/16/16.pdf

Shamsutdinova, T. M. (2020). Cognitive Model of Electronic Learning Trajectories Based on Digital Footprint. Open Education, 24(2), 47-54. https://doi.org/https://doi.org/10.21686/1818-4243-2020-2-47-54

Shkola i koronakrizis: kak izmenitsya obrazovaniye [School and Coronovirus: How Education Will Change]. (2020). Deti $v$ Informatsionnom Obshchestve [Children in the Information Society], (32). http://detionline.com/assets/files/journal/32/dio32 2020 web.pdf

Skiba, S. A., \& Loiko, V. I. (2013). Social Scoring. Polythematic Online Scientific Journal of Kuban State Agrarian University, 91, 1508-1517. https://www.elibrary.ru/item.asp?id=20678980 
Smutny, Z., \& Vehovar, V. (2020). Social informatics research: Schools of thought, methodological basis, and thematic conceptualization. Journal of the Association for Information Science and Technology, 71(5), 529-539. https://doi.org/https://doi.org/10.1002/asi.24280

Sokolov, A. V. (2012). Informatsionnoye obshchestvo v virtual'noy i sotsial'noy real'nosti [Information Society in Virtual and Social Reality]. Aleteyya.

Soldatova, G., Rasskazova, E., Zotova, E., Lebesheva, M., Geer, M., \& Roggendorf, P. (2012). Deti Rossii onlayn. Rezul'taty mezhdunarodnogo proyekta EU Kids Online II v Rossii [Russian Kids Online Key findings of the EU Kids Online II survey in Russia]. http://detionline.com/assets/files/helpline/Russian KidsOnline Final Report 2013.pdf

Soldatova, G. U., Nestik, T. A., Rasskazova, Y. I., \& Zotova, Y. Y. (2013). Tsifrovaya kompetentnost' podrostkov i roditeley. Rezul'taty vserossiyskogo issledova [Digital competence of adolescents and parents. Results of an all-Russian study]. Fond Razvitiya Internet. https://ifap.ru/library/book536.pdf

Soldatova, G. U., Rasskazova, Y. I., \& Nestik, T. A. (2017). Tsifrovoye pokoleniye Rossii: kompetentnost' $i$ bezopasnost [Digital Gneration of Russia: Competence and Safety]. Smysl. https://www.rfbr.ru/rffi/ru/books/o 2076613

Soldatova, G. V., Zotova, Y. Y., Chekalina, A. I., \& Gostimskaya, O. S. (2011). Poymannyye odnoy set'yu: sotsial'nopsikhologicheskoye issledovaniye predstavleniy detey i vzroslykh ob internete [Caught by the Same Net: A SocioPsychological Study of Children's and Adult Ideas about the Internet]. https://ifap.ru/library/book524.pdf

Soldatova, G. V., Rasskazova, E. I., \& Chigarkova, S. V. (2020). Types of Cyberaggression: Adolescents and Youth Experience. National Psychological Journal, (2), 3-20. https://elibrary.ru/item.asp?id=44044953

Sotsial'nyy spros na innovatsii. (2015). Sotsial'nyy spros na innovatsii. https://www.hse.ru/monitoring/innpeople/2015rus

Stepanov, V. N. (2014). Fasting as a Tool for the Formation of Social Capital in the Social Network (On the Example of Social Network Facebook). Herald of Tver State University. Series: Philology, (1), 183-191. https://www.elibrary.ru/item.asp?id=21570760

Sto druzey podrostka [A Hundred Teenage Friends]. (2018). Deti v Informatsionnom Obshchestve [Children in the Information Society], (24). http://detionline.com/assets/files/journal/24/24nomer.pdf

Sudakova, A. E. (2020). Migration of scientists: digital footprint and scientometry. Perspectives of Science and Education, (3), 544-557. https://doi.org/10.32744/pse.2020.3.39

Surguladze, V. S. (2020). Social Media as a Tool of Socio-Political Destabilisation of Society: Lessons, Trends, Prospects. Gumanitarnie Nauki. Vestnik Finansovogo Universiteta, 10(1), 6-13. https://doi.org/10.26794/2226-7867-2020-10-1-6-13

Sushchestvuyut li tsifrovyye aborigeny? [Do digital natives exist?]. (2014). Deti v Informatsionnom Obshchestve [Children in the Information Society], (14). http://detionline.com/assets/files/journal/14/number14.pdf

Tarankov, O. I., \& Poroshkina, T. S. (2020). The Problem of Security When Using Biometric Data of Citizens. Vestnik Moskovskogo Avtomobilno-Dorozhnogo Gosudarstvennogo Tehnicheskogo Universiteta, (4), 159-164. https://doi.org/10.31085/2310-8681-2020-4-208-159-164

Tekhnofily i tekhnofoby [Technophiles and technophobes]. (2016). Deti v Informatsionnom Obshchestve [Children in the Information Society], (25). http://detionline.com/assets/files/journal/25/25.pdf

Tendryakova, M. V. (2015). Igrovyye miry ot Homo ludens do Geym [Game Worlds from Homo ludens to Gamer]. NestorIstoriya.

Tkacheva, A. (2020). Modern Methods of Committing Crimes Related to Bringing Juveniles to Suicide Using Social Networks and Responsibility for Them. Legal Science and Practice: Journal of Nizhniy Novgorod Academy of the Ministry of Internal Affairs of Russia, (3), 223-227. https://doi.org/0.36511/2078-5356-2020-3-223-227

Tokarev, Y. M. (2016). Sotsial'naya informatika [Social Informatics]. https://www.volgmed.ru/uploads/files/2018-11/96531socialnaya informatika.pdf

Tsvetkova, N. A., \& Kuznetsov, N. M. (2020). Phenomenon of Big Data Diplomacy in World Politics. RSUH/RGGU Bulletin. Series Political Sciences. History. International Relations, (4), 27-44. https://doi.org/10.28995/2073-6339-2020-4-27-44

Tuzovskii, I. D. (2019). Soft Power as a Basis of the Cultural Politicy in the Digital Age. Culture and Arts Herald, (1), 91-96. https://www.elibrary.ru/item.asp?id=37212710

Ursul, A. D. (1990). Informatizatsiya obshchestva i sotsial'naya informatika. [Informatization of society. Introduction to social informatics]. In Sotsial'naya Informatika. AON pri TsK KPSS [AON at the Central Committee of CPSU].

Vagarina, N. S., Mel'nikova, N. I., \& Shul'ga, T. E. (2017). Sotsial'nyy netvorking. Vuzovskoye obrazovaniye. https://elibrary.ru/item.asp?id=30659952

Vasilev, A. A., \& Mukhopad, V. V. (2020). The Problem of "Identity Theft" in Russian Law. Russian-Asian Law Journal, (3), 38. https://doi.org/https://doi.org/10.14258/ralj(2020)3.1

Vasilkova, V. V., \& Legostaeva, N. I. (2020). Social Bots in Computational Propaganda: Surfing the Coronavirus Information Wave. Monitoring of Public Opinion: Economic and Social Changes, (6), 329-356. https://doi.org/10.14515/monitoring.2020.6.1762

Videoigry: bolezn' veka ili faktor razvitiya? [Video games: disease of the century or development factor]. (2017). Deti $v$ Informatsionnom Obshchestve [Children in the Information Society], (27). http://detionline.com/assets/files/journal/27/№27 web.pdf

VINITI RAS DB Online. (2021). VINITI RAS DB Online. http://bd.viniti.ru/index.php?option=com content\&task=view\&id=238\&ltemid=101 
Vitetskaya, L. V. (2016). Sotsial'naya informatika. http://moodle.pnzgu.ru/mod/resource/present.php?id=20558\&section=2

Vo chto igrayem? [What are we playing?]. (2009). Deti v Informatsionnom Obshchestve [Children in the Information Society], (2). http://detionline.com/assets/files/journal/2/journal-2.pdf

Voronin, D. Y., \& Kuznetsov, P. N. (2021). Agent-Based Modelling of Societal Consolidation Dynamics Using Internet Content Cyber-Metrics Algorithms. Obshchestvo: Sotsiologiya, Psikhologiya, Pedagogika, 83(3), 25-30. https://doi.org/10.24158/spp.2021.3.3

Vospitat' Tsezarya [Raising Caesar]. (2017). Deti v Informatsionnom Obshchestve [Children in the Information Society], (28). http://detionline.com/assets/files/journal/28/28 web.pdf

Voyskunskiy, A. Y. (Ed.). (2009). Internet-zavisimost': psikhologicheskaya priroda i dinamika razvitiya [Internet addiction: the psychological nature and dynamics of development]. Akropol'.

Yandex Podbor Slov. (2021). Yandex Podbor Slov. https://wordstat.yandex.ru/

Yarmak, O., Strashko, E., \& Shkayderova, T. (2020). How Internet Users in Moscow, Saint-Petersburg and Sevastopol Reactedt to the Covid-19 Pandemic (Based on Material From a Media-Analysis Study). Bulletin of the Institute of Sociology, 11(3), 121-142. https://doi.org/10.19181/vis.2020.11.3.666

Yedinaya gosudarstvennaya informatsionnaya sistema ucheta nauchno-issledovatel'skikh, opytno-konstruktorskikh i tekhnologicheskikh rabot grazhdanskogo naznacheniya (EGISU NIOKTR). (2021). EGISU NIOKTR. https://www.rosrid.ru/

Yedinyy urok bezopasnosti [Unified safety lesson]. (2017). Deti v Informatsionnom Obshchestve [Children in the Information Society], (28). http://detionline.com/assets/files/journal/26/26.pdf

Yegorova, L. G. (2014). Filosofiya informatsionnogo obshchestva. https://kpfu.ru/pdf/portal/oop/19637.pdf

Yelkina, E. E., Kononova, O. V., \& Prokudin, D. E. (2019). Typology of Contexts and Contextual Approach Principles in Multidisciplinary Scientific Research. Modern Information Technologies and IT-Education, 15(4), 141-153. https://doi.org/10.25559/SITITO.15.201901.141-153

Yevdokimova, V. Y. (2016). Sotsial'naya informatik. http://shgpi.edu.ru/files/obr standart/edu programms/2016/39.03.02 socialnaya rabota (profil socialnaya rabota $v$ ra zlichnih sferah deyatelnosti //work programms/bb/b1.b.20.pdf

Yudin, B. G. (2006). Ot gumanitarnogo znaniya k gumanitarnym tekhnologiyam [From humanitarian knowledge to humanitarian technologies]. In Gumanitarnoye znaniye: tendentsii razvitiya v XXI veke: v chest' 70-letiya Igorya Mikhaylovicha Il'inskogo (pp. 187-214). Izd-vo Nats. in-ta biznesa.

Zagorodnyuk, Y. V. (2017). Sotsial'nyye problemy informatizatsii [Social problems of informatization]. YURGPU (NPI).

Zharova, A. K. (2020). Issues of Ensuring Security of a Person's Digital Profile. Yurist, (3), 55-61. https://doi.org/10.18572/1812-3929-2020-3-55-61

Zherdev, P. A. (2000). Electron-Digital Traces as an Element of the Criminalistic Characteristic of Crimes in the Field of Computer Information. Vestnik of Far Eastern Law Institute of the Ministry of Internal Affairs of the Russia, (2), 94-101. https://mvd.ru/upload/site134/document text/003/379/142/Annotatsii klyuchevye slova 2020 2.pdf

Zhiburt, P. E., Kazarova, V. S., Kruchinkina, E. V., \& Chikunova, A. E. (2021). Properties of Mass Consciousness in the Digital Economy. Scientific Research of Faculty of Economics. Electronic Journal, 13(1), 82-95. https://doi.org/10.38050/2078-3809-2021-13-1-82-95

Zilberman, N. N. (2017). Is Hello Barbie an Interactive Doll or Social Robot? Humanitarian Informatics, (12), 32-39. https://doi.org/10.17223/23046082/12/4

Editorial record: The article has been peer-reviewed. First submission received on 26 July 2021. Revision received on 1 October 2021, 11 December 2021 and 31 December 2021. Accepted for publication on 31 December 2021. The editors coordinating the peer-review of this manuscript were Vasja Vehovar (D), Zdenek Smutny (D), and Alice R. Robbin (D). The editor in charge of approving this manuscript for publication was Zdenek Smutny.

Special Issue: Perspectives of Social Informatics.

Acta Informatica Pragensia is published by Prague University of Economics and Business, Czech Republic.

ISSN: $1805-4951$ 